\title{
LONG-TERM PROVISIONS AS A SECURITY MECHANISM DUE TO A LACK OF QUALITY
}

\author{
Milica Ristic, Radenko Milojevic, Marija Radosavljevic* \\ Faculty of Economics, University of Nis, Nis, The Republic of Serbia
}

Modern business conditions have decisively been indicating that quality is the basis of the competitiveness of a company. A lack of quality creates dissatisfaction and affects customer loyalty. Lately, there has been a tendency of the growth of non-quality costs, which is a consequence of a lack of the quality of the products delivered. Although numerous studies suggest models for calculating non-qualitative costs, no relevant mechanism has been found yet to manage these costs. In this study, the authors attempted to find a link between long-term provisions and the external failure cost since this relation has not received other researchers' attention so far, as it deserves. The aim of the research is to point out the importance of longterm provisions as relevant instruments to control external failure costs. Different surveys have confirmed the initial assumption and showed that long-term provisions are effective instruments for managing the costs of external failure. A positive, statistically significant correlation between long-term provisions and the net profit of a company was also identified among the first 100 enterprises from the list of the most successful enterprises in the Republic of Serbia in 2017.

Keywords: quality, quality costs, external failure costs, long-term provisions

JEL Classification: L52, M21, M41

\section{INTRODUCTION}

The competition that operates on the market with a propulsive force imposes a requirement for all participants, even small businesses included, that they cannot survive without effective financial and economic management. It is companies' ambition to

* Correspodence to: M. Radosavljevic, Faculty of Economics, University of Nis, Trg Kralja Aleksandra Ujedinitelja 11, 18000 Nis, The Republic of Serbia;

e-mail: marija.radosavljevic@eknfak.ni.ac.rs. operate in accordance with market demands, survive on the market, increase their financial and economic effectiveness, and develop (Eben-Chaime, 2013).

Business philosophy in contemporary conditions emphasizes the importance of quality as one of the important factors of business success. "Although it has been more intensely mentioned and written about since the last few decades of the $20^{\text {th }}$ century, quality is immanent in human nature and can be said to be 'older' than the company" (Bošković and 
Anđelković Pešić, 2011, 2). However, we should bear in mind the fact that quality, or a set of the product attributes necessary to meet customer needs, is of a changing nature. Therefore, in order to control the quality of products/services, it is necessary for a company to act reactively or proactively (Vučićević and Anđelković Pešić, 2012). The reactive activity of a company includes the activities directed towards dissatisfied customers. A proactive action includes the activities undertaken by a company in order to prevent the occurrence of defects and the occurrence of dissatisfied customers. A set of all the activities of a company's reactive and proactive procedures is being paid special attention in academic circles. Companies are increasingly starting dealing with quality control issues, looking at quality as a factor of competitive advantage. Analogously, managing quality costs is becoming an imperative of the new economy.

Although numerous classifications of the cost of quality can be found in the literature, the majority of authors have accepted the cost structure of quality provided by A. V. Feigenbaum (1994). According to that author, the cost of quality can be divided into prevention costs, detection costs, internal failure costs and external failure costs. Prevention costs arise as a result of the activities aimed at preventing a potential lack of quality and the possibility that non-compliant products might reach customers. Detection costs arise from a company's efforts to detect the degree of the compliance of its products with quality requirements in order to satisfy consumer demands. Quality control is precisely paid attention to due to the costs involved in determining whether a proper quality is maintained. However, globalization and increasing consumer demands have made it impossible for companies to manage only these quality costs. There is an increase in internal and external failure costs. Therefore, these costs are referred to as nonreturn/failure costs. Non-quality costs arise when a product of an inadequate quality is created. As such, they predispose "the difference between the actual operating costs and the operating costs that would have resulted if there had not been a failure in the company's systems incurred by its employees" (Krishnan, Agus \& Husaain, 2000, 844). Internal failure costs arise when the manufacturer discovers an error while assembling a product, whereas external failure costs arise when a product error is detected by a customer. Internal failure costs include: the costs of the defect analysis, replacement costs, treatment costs and repairs, re-inspection and testing costs, elimination costs for defective products, opportunity costs, and waste costs. External failure costs include the costs of withdrawing products from the market, the costs resulting from lost sales, the costs of returned products with a warranty period, the shipping costs arising from returned products, the costs of product servicing (Vučićević and Anđelković Pešić, 2012, 498). External failure costs are a result of the dissatisfied consumers who lodge a complaint about the product of an unsatisfactory quality and seek interventions within the warranty period or a refund. These costs can have consequences for the company's business, if the company does not have enough resources to provide new products within the warranty period.

The subject matter of this study are the costs of quality, or more precisely the costs of external failure that occur due to a lack of the quality expected by consumers. This research study is aimed at pointing out the importance and role of long-term provisions for the management of quality costs, starting from the assumption that long-term provisions can be particularly efficient tools for managing the costs of external failure. Identifying the costs of external failure and security in the event of their reporting are very important because quality is one of customer demands, together with the time of delivery, the price and the flexibility of products, which are the key competitive priorities in contemporary conditions" (Krstić, Anđelković Pešić and Anđelković, 2010, 346). Bearing in mind the nature of long-term provisions, the above-stated assumption is expected to be confirmed through the study.

For the purpose of examining long-term provisions, a wide range of research methods were applied. The induction method was used to analyze all the costs of quality and make general conclusions. The methods of analysis and synthesis were used to examine long-term provisions. The historical method and the method of compilation were applied to analyze similar studies in this field. Correlation analysis and variance 
analysis were used as the appropriate methods of statistical analysis. The hypothesis was tested out by applying the desk method, which involves the use of professional and scientific literature.

The study assumed that long-term provisions were effective instruments for managing external failure costs and that there was a positive quantitative concurrence between long-term provisions and the net profit of a company.

In the first part of the paper, a review of the literature on quality costs and long-term provisions is given. The second part analyzes the role of longterm provisions in cost management. In the third section, whether long-term provisions can be an effective tool for reducing the consequences of an inadequate quality or not is examined. The fourth part contains the conclusions. Based on the results obtained, a guideline for further research is expected to be drafted. The paper seeks to promote a good assessment of long-term provisions in order to protect against modern business risks.

\section{COST OF QUALITY MANAGEMENT}

The concept of quality can be attributed to the 1950s and a group of researchers including Edwards Deming, Joseph Juran, and Armand Feigenbaum. Back then, the measurement and reporting of quality costs was the first step towards quality management. Over time, the cost of quality has become a "golden mine" of companies and the current topic in academic circles. The greatest attention was paid to prevention costs, according to which quality was well-managed by managing this type of costs. According to Juran "quality implies the convenience of use", and this author pointed to the great importance of prevention costs. His model of optimum quality costs created the basics for further research in the field of quality costs (Bošković and Anđelković Pešić, 2011, 2).

The philosophy of quality costs expanded in academic circles in the post-1990s. D. Bamford and N. Land (2006) emphasizes that a quality cost analysis can be done best if all quality costs are taken into account. A comprehensive analysis of quality costs that contributes to product and service costs was also provided by A. Sailaja, P. Basak and K. Viswanadhan (2015). Their research results indicate that there are hidden quality costs which can be up to three times as high as the known quality costs. However, according to the authors all quality costs can be reduced or even eliminated by the proper monitoring and understanding of the underlying causes.

Without quality products, companies cannot achieve the expected profit. Not only do errors create unnecessary costs in a company, but they also hinder the production process, leaving the consequences that can lead to a production stoppage (Campanella, 1999). A. Schiffauer and V. Thomason (2006) provided an overview of the published literature on different approaches to quality and the successful implementation of these approaches, pointing out that access to quality costs must match the situation, goals, and needs of the company and the environment. S. Bisgaard (2007) points out that, based on the existing studies on the subject matter, no "perfect" approach to the management of quality costs can be given although Juran managed to synthesize the topic and provide a coherent framework and terminology. Juran predicted many principles that were later incorporated under the "Six Sigma Umbrella" (Bisgaard, 2007, 665). Also, other advocates of the quality theory provide the significant methods, techniques and instruments that not only facilitate cost-benefit management, but also enable efficient corporate governance. "However, not one of the approaches offers concrete solutions and not a single such solution could be considered as a concrete solution for a particular company" (Bošković and Anđelković Pešić, 2011b, 56).

Internal and external failure costs have increasingly participated in total costs. According to A. V. Feigenbaum (1994), non-quality costs represent 65$70 \%$ of the total quality costs. The emphasizing of the importance of non-value costs results from their detection by customers, which can significantly affect a company's business. The buyer, the most important link in a company's business, dissatisfied with the quality of a product, can influence the company to start operating at a loss. Namely, the number of 
returned products is inversely correlated with a gain. If there is an increase in the number of complaints, the issue of the company's survival opens. Finally, "prevention costs will achieve the ideal value when cancellation costs are brought to a tolerant level" (Raupp, Gaebler, 2016, 284).

T. Malmi, P. Järvinen and P. Lillrank (2004) emphasized the fact that it was impossible to use traditional methodologies when the management of non-quality costs was concerned. In their research study, the authors presented an approach to managing these costs. In line with modern business conditions, internal failure costs are gaining an increasing role in planning. However, the problem is the fact that "many external failure costs are not included in the quality costs". Therefore, there is a problem of managing external failure costs, with respect to which whether they will arise at all or not is unknown. According to the results of the research project, costs can be managed by introducing the use of the perspective value and the probability of occurrence. External failure costs, or a lack of quality costs, are "all those costs that would disappear if the production process were perfect" (Teli, Majali, Bhushi, \& Surange, 2012, 330). External failure costs arise when the quality that is missing has direct implications for the consumer. This results in certain business risks. The consumer demands the reclamation of the product, an intervention in the warranty period, returns the product and expands the information about the quality.

The model designed by J. Chi-Tsou (2007) confirms that defective products and non-quality costs are one of the factors lying behind a decline in corporate profits. The changes caused by defective products affect a reduction in annual profits. In their study, $\mathrm{H}$. Ali, W. Arif, D. Pirzada, A. Khan and J. Hussain (2012), focused on the non-performance costs of a production unit in Pakistan, analyzing the costs of the internal and external deficiencies. The authors provided a model aimed at minimizing and eliminating failure costs, including costs arising from warranties. Essentially, the most important thing in reducing non-quality costs is to set priorities for an effective use of resources, which is possible to accomplish by identifying the factors contributing to the emergence of the same (Ali et al, 2012). F. M. Raupp and D. M. Gaebler (2016) identify non-quality costs, and provide a classification of quality costs according to the authors in the period from 1990 to 2003. The authors point to the importance of their research study from the academic point of view due to scarce studies in this field. The results of the research indicate that the non-quality cost exceeds quality costs.

"Where there is a need for control of something, the first thing to do is measure. If something is not quantitatively expressed, we cannot manage and control it" (Krishnan, Agus \& Husain, 2000, 844). It is very difficult to predict external failure costs because they depend on the type of industry, the level of the implementation of quality management, and many other factors. Therefore, the study of the mechanisms that enable a realistic estimate of the non-quality cost is of great importance.

The importance of the management of external failure costs can be seen in the negative correlation between quality management costs and the costs of internal and external failures (Figure 1). Unlike the other types of quality costs, these costs grow when the cost of quality decreases. In the zone of decreasing quality costs per product, the costs of internal and external failures go beyond $70 \%$ of the total quality costs, prevention costs, detection costs, internal failure costs, and external failure costs.

In order to achieve a satisfactory quality, it is necessary to reduce the non-quality cost (Fu \& Zhang, 2016). There is another argument in favor of the importance of external failure costs. Quality costs can also be differentiated by activity. From this aspect, the most important costs are exactly those in the productuse phase, i.e. the costs that accompany the postproduction process. These costs involve the warranty period, quality costs, product servicing costs, and product maintenance costs.

S. Baiman, P. Fischer and M. Rajan (2000) analyzed the relationship between product quality and quality costs. The authors examined the successfulness of incorporating a special information system, which would reduce inefficiency and external failure costs. 


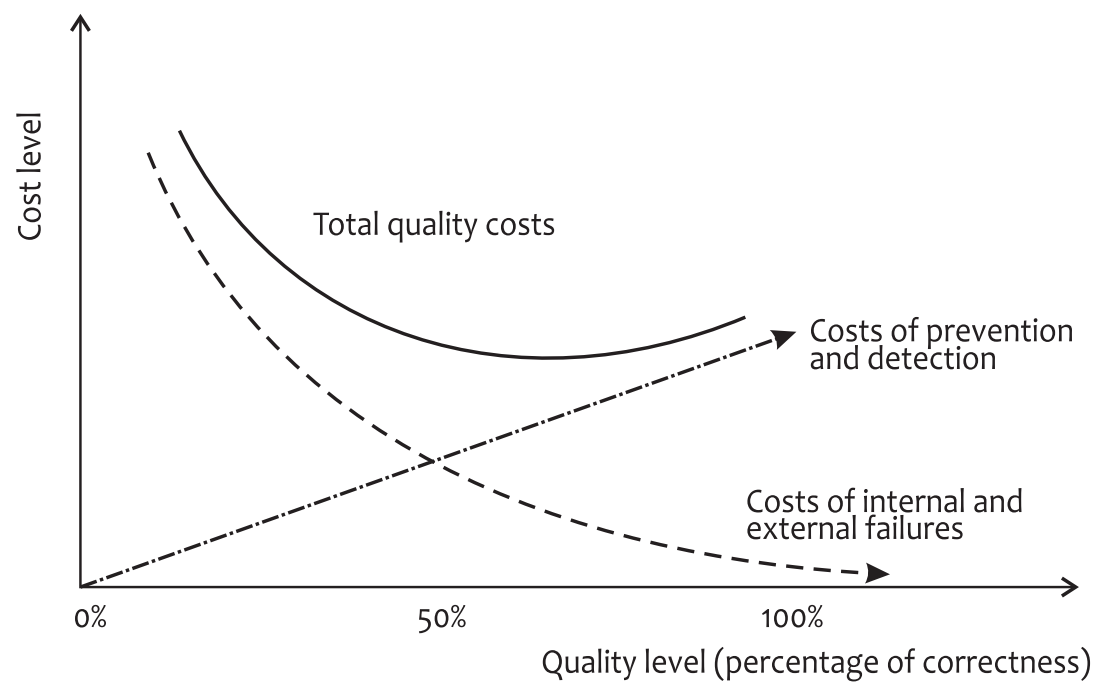

Figure 1 The movement of quality costs

Source: Bošković and Anđelković Pešić, 2011, 171.

S. N. Teli et al (2014) conducted an experimental research study in the field of the automotive industry. In order to test profitable business management, the authors assessed the market-oriented aspects of quality costs. "Tracking non-qualitative costs would help analyze operating costs" (Teli et al, 2014, 1757). Based on the collected data, the authors performed a graphic analysis of the impact of the quality costs on the company's operations. One of the methods for reducing the non-qualitative costs is analised by $C$. Barbará, C. Eutrópio E. de Souza i R. Catunda (2008). They analyzed non-production costs, problems of nonconformity, failure of service activities and loss of revenue due to lack of quality. It is considered that quality control should begin at the design stage of the product (Bošković \& Anđelković Pešić, 2011). However, despite the positive effects of such a control, it seems to be insufficient in modern business conditions. Taking this into account, V. Vučićević and M. Anđelković Pešić (2012) examined a lack of quality consequences and pointed to the importance of control.As an important determinant of business operations, controlling was also examined by A. Satanova and M. Sedlicikova (2015). Focusing on nonquality costs control, the authors emphasized the fact that control and cost management were linked to the principles of the TQM philosophy. Finally, the author's opinion that "controlling provides a framework for the application of statistical quality control, designing experiments, improving quality, and applying the reliability method" (Bisgaard, 2007) points to the need for analyzing the correlation between the management of the cost of quality and controlling, or testing the role of controlling and the corresponding instruments in the process of managing the costs of quality.

\section{LONG-TERM PROVISIONS AS A CONTROLLING INSTRUMENT}

Controlling is a good way of managing from the aspect of accounting, which is necessary to preserve the basics of control (Wojtaszek, 2016). It is necessary to estimate the governance process in particular in the assessment of financial results with a particular focus on cost analysis. Long-term provisions are identified as one of the controlling instruments used in risk protection business.

A wide range of allocations for a variety of risks could be seen in France and Germany even back in the 
1960s. Provisions included provisions for disputes, guarantees given to customers, fines and penalties, losses at exchange rates, employee participation in development effects, rebates, differences in taxes, even for pensions, annual leaves. All this points to the importance of provisions for the functioning of a company.

Long-term provisions belong to borrowed capital. However, as a category of borrowed capital, they represent a specific obligation of an exact character, and accordingly differ from the other categories of borrowed capital. The obligation implies the present obligation arising from the previous event (by the act of sale, the company undertakes to implement certain activities for which it gave a guarantee to the buyer, these activities occurring in several years). The settlement of the resulting obligation will naturally lead to an outflow of precisely defined company resources. In the case of provisions, the exact amount and the exact maturity of the obligation (reclamation) are unknown on the balance sheet date, and therefore provisions differ from other obligations. Long-term provisions are the liabilities that are not valued on the basis of a document, but their valuation is based on an estimate. Long-term provisions are different from potential liabilities. A provision is an obligation that exists on the balance sheet date, and a contingent liability is not current and does not exist on the balance sheet date. A potential obligation is a possible obligation. According to the International Accounting Standard IAS 37 (paragraph 10), "the provision of liabilities with an uncertain maturity or amount" (IAS $37,2009,16$ ). An obligation is the present obligation of the company that came from the past event that would result in the outflow of economic benefits from the company. If there is no past event, there is no obligation relationship that creates an obligation, so there is no provision.

Thus, in order to make a provision, it is necessary to fulfill the two conditions:

- liabilities exist on the balance sheet date, i.e. there is an obligatory relationship based on the law or custom,

- the amount and the deadline of the obligation are not known, there is a great uncertainty (provisions are more uncertain even from a passive time delimitation), but again there is a need for a certain expectation of an actual creation.

A past event can create two types of obligations: a legal obligation and a constructive obligation. A legal obligation arises from a contract, either legally, or under the force of the law, for example a court decision. A constructive obligation arises from some of the activities carried out by an entity, with respect to which it is known that the same will arise from practice or a statement of responsibility acceptance ${ }^{1}$. There is essentially no difference between the provisions created on the basis of legal or constructive obligations - in both cases they are followed by the same accounting treatment. Recognizing whether it is a legal or constructive obligation indicates the time when provision is recognized.

The "basis" of a provision is given by the principle of income and expenditure causation and the principle of prudence. It means that, if income is realized in the current period, for example based on the sale of some goods, it is logical that expenditures will arise from the issuance of those goods, which will arise in a future period as a result of the revenues for the current period. These expenditures will be recognized as current-year expenditures. Including such expenditures in the Balance Sheet Long-term Provisions is always accompanied by an increase in expenses in the Income Statement and a decrease in the periodic result. Also, if revenues are higher than expenditures, the provision will be covered by revenues and will appear in the form of liquid assets in the assets of the Balance Sheet. Until the moment of the payment of the expenses based on which provisions are made, the funds derived from the revenues of the covered provisions can be used to finance other needs. The characteristics of borrowed capital are seen here because provisions in this case appear as the sources of funds.

In the literature and legislation, no general risk list, i.e. the basis for forming provisions against third parties, is provided. In France, provisions represent a special position of the existing capital. Therefore, these are the obligations of the current and the previous accounting periods according to future 
accounting periods. The financial reporting rules require that the costs that arise in the future are recognized in the financial statements in the form of provisions in the current period. Expenses should be recognized in the period in which they are caused, and their recognition should not be postponed until the moment they actually occur.

In order to place provisions in the role of managing non-qualitative costs, it is necessary to evaluate and "recognize" them. The recognition of provisions under IAS 37 implies that the three conditions are met:

- the present obligation;

- the probability of the outflow of resources to settle the obligation;

- a reliable assessment of the obligation.

It is very important that a past event, a sale of products, which created the present obligation towards the buyer, does not leave the company another alternative but to settle the recognized obligation. The probability of the outflow of resources is an assumption justifying the opening of the account - Long-term provisions.

The best estimate of the obligation would be equal to the expenditure needed to settle the present obligation at the balance sheet date. This means that the risks and events that will follow must also be taken into consideration. An assessment is performed by the company's management based on the company's act . If the company has not recognized reserves so far, the best estimate is that based on the competition in the branch. Each company should be obliged to elaborate the issue of provisions since their assessment and the possibility of recognition depend on the situation.

In accordance with the complexity of this account, a wrong or unnecessary recognition often occurs in practice. Business losses are frequently regarded as an obligation although they do not have a past event and it is logical that there will be no long-term provisions. Future business losses can be avoided by using some prevention measures or by selling a part of the business. In order to avoid the overestimation or underestimation of the financial statement positions, a valuation of property objects at purchase prices or at cost prices is carried out. More precisely, financial statements are made in accordance with the prudence principle. Analogously to the prudence principle, the basis for the assessment of long-term provisions should be the principle of reliability, so that there is certainty that the assessment is reliable. The accounting standard IAS 37 insists on a reasonable assessment and if a provision meets the conditions of recognition, it will not be recognized if the estimate of the economic benefits outflow in this case is unreliable.

The engagement of an expert in assessing the provision for the costs in the warranty period plays a very important role. In accordance with the fact that only a professional accountant can provide the quality of financial reporting, specialists for the assessment of long-term provisions can also provide a quality and competent assessment. There is also a need for establishing a link between the accounting policy, the quality policy, and the policy of the engineers who will make an assessment. Therefore, it is necessary to have a perspective not only from the accountant's aspect, but also from the aspect of finance, marketing and engineering. After long-term provisions have been estimated, the amount of the assessment is reviewed each year and, if necessary, certain adjustments are made. Changes may occur on each day of the balance sheet and if it is no longer probable that the settlement of the obligation will require the outflow of economic benefits, the provision should be canceled for the benefit of the revenue.

"Creative financial reporting can seriously undermine the usability of financial statements" (Malinić, 2009, 156; Brandt, Biesebroeck \& Zhang, 2012; Đukić $\&$ Pavlović, 2014). The provision policy requires constant checking and corrections as a provision must continuously be monitored so as to reflect the best current estimate. Due to uncertainty, the amount of the reservation can be changed. Each correction implies an expense or income, and affects the result. In empirical researches on long-term provisions the companies that improve their performance by increasing long-term reserves are described. An incorrectly displayed end result can create an incorrect image with the investors and redirect them towards investing in another company. It can also 
discourage creditors in terms of lending or reduce the value of the shares and dividends if the profit is drastically reduced. Therefore, particular attention should be paid to the assessment of this account in order to minimize the consequences.

When estimating long-term provisions, the effect of money is very significant in some cases, especially if the time limit is longer than a year. The provisions related to the cash outflows that arise immediately after the balance sheet date are of course more valuable than the cash outflows of the same amount that arise later. In such cases, provisions should be discounted.

If the amount of a provision is unrealistically estimated and provisions are overestimated, latent reserves are generated; otherwise, hidden losses are generated. Latent reserves reduce the periodic performance of the business, as it has overestimated the position of liabilities. Due to the impact on the business result, latent reserves are often defined as part of the realized gain which is not reported. The opposite balance category of latent reserves are the hidden losses that are due to the underestimation of liabilities. Underestimated liabilities affect the formation of a lower amount of expenditures in the Income Statement and an increase in the calculated short-term financial result. Any hidden loss in the Balance Sheet is disclosed in the Income Statement in subsequent accounting periods. The disclosure of hidden losses in this case will depend on the rate of maturity. Latent reserves and hidden losses spoil the picture of the financial position of a particular company. Therefore, they should strive to minimize them, i.e. reduce their long-term resilience to their real value.

\section{LONG-TERM PROVISIONS AS A TOOL FOR REDUCING THE CONSEQUENCES OF INADEQUATE QUALITY}

New quality requirements increase business risk and make it more and more likely to rely on the resources it has reserved. Customers will be increasingly demanding in terms of reclamation and if the company does not allocate funds in a separate account, it will have to face high costs of inefficiency. In the Republic of Serbia, according to the Rulebook on the Chart of Accounts and the Content of the Account in the Chart of Accounts for Companies, Cooperatives, Legal Entities and Entrepreneurs, there are the following types of provisions within Group 40 - Long-Term Provisions: provisions for expenses in the guarantee term; provisions for the costs of natural resources renewing; provisions for retained bonds and deposits; provisions for restructuring costs; provisions for reimbursements and other employee benefits; provisions for costs of litigation; other longterm provisions ${ }^{2}$.

For the purpose of the research study, the most important type of provision is that for expenses in the warranty period, which can protect a company from risky products. The main reason for the formation of a provision for this purpose is to strengthen the position of customers in relation to the manufacturer, as well as the increasing demands and the constant expansion of the product range, the sale of which is followed by giving guarantees.

The fact that it is necessary, not only implicitly, but also explicitly, to manage non-quality costs justifies the subject matter of our research. Figure 2 shows the place of long-term provisions in modern business conditions.

Namely, the possibility of a certain number of requests for the fulfillment of obligations under the given guarantees can create great costs for the company. Due to the risk and uncertainty of the emergence of this obligation, there is a need to allocate certain funds. Namely, the obligation to form a provision for costs in the warranty period arises because the time period of the warranty period exceeds the accounting period in which the sale was made. The past event that is binding on the recognition of this account is the sale of goods, based on which the present obligation, i.e. a promise to cover repair costs within the warranty period, was created. Therefore, it is certain that there will be an outflow of cash, while the amount and the maturity period are uncertain. Determining the amount of a provision is most often based on the 


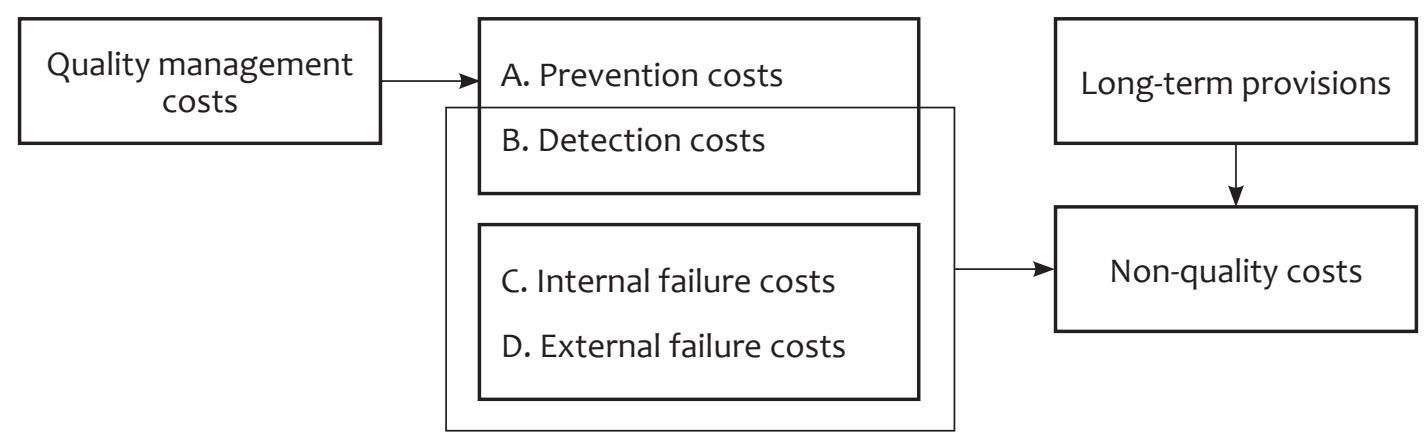

Figure 2 The location of long-term provisions in the cost matrix

Source: Authors

previous experience for the same or similar goods. Bearing in mind the problems that can arise during the inclusion of these business transactions, which are due to an unstable calculation basis and the impossibility of an absolutely accurate allocation of revenues and expenditures, a comparison of accounting practice plays an important role (Malinić, 2009). If there were no previous costs on this basis, the estimate of the provision is made by observing the competition in the same branch. Of course, the amount of the provision depends on the volume of sales, so it is most often expressed in the percentage of the sales realized. Provisions are carried out in groups, i.e. for a product group. However, if a company has a large number of products in its assortment with different probabilities and risks for reclamation, then certain groups of products for which provisions will be recognized should be made. Provided that a company continuously sells the products for which a guarantee is offered, the provision for expenses in the warranty period has the character of a continuous provision.

"By definition, long-term provisions represent liabilities for covering the costs of and risks from previous activities that will emerge in the coming years" (Lukić, 2017, 455). In this sense, the assumption is that long-term provisions are a mechanism by which it is possible to manage the costs of external cancellations efficiently in order to ensure risks from their occurrence. Visibility, or an insight into the flows and processes that continue outside an enterprise, is becoming a very important basis for good business operations. Exposing to a risk of providing product warranties in modern business conditions creates the costs that are very difficult to estimate. "For commercial products, the price and the guarantee are the two key marketing strategies used to increase market share" (Xie, 2017).

The significance of a warranty came to light even decades ago. Namely, J. Mamer (1987) exposed his model of costs and benefits arising from guarantees. The author considered three types of product warranty, as well as the potential damages that result from a lack of quality. His model was the basis for a further analysis of the compromise between the guarantee and quality control.

The study conducted in Greece also highlights the importance of long-term provisions as effective tools for the reduction of non-value costs. According to this study, $89 \%$ of long-term provisions play a role in reducing non-quality costs (Chatzipetrou \& Moschidis, 2016). According to S. Amberkur and M. M. Jagdtap (2014), long-term provisions depend on the type of guarantee, the reliability of the product, the warranty period and the type of the product. A large number of customers purchase products with an extended warranty, which companies could only provide if they relied on a relevant controlling instrument (Maronick, 2007).

Only a few studies dealing with the impact of longterm provisions on the management of quality costs 
have involved companies in the Republic of Serbia. According to R. Lukic (2014), the rate of the return of goods from sales is becoming an increasingly important indicator of the level of consumer satisfaction and the performance of retail chains. By a comparative analysis of the return of goods in the United States and Canada, the author explores the impact of long-term profit reserves and suggests that adequate control should minimize the effect of return. The author conducted a theoretical and empirical analysis of the impact of long-term provisions on the costs of external failure. According to the author, the costs of external provisions need to be managed efficiently in order to obtain as much profit as possible. The author analyzes the cost of the guarantee according to the type of goods and emphasizes the fact that the return or replacement of a product due to its inadequate quality has created high costs in numerous industries. The results of his research show that long-term provisions are an increasingly important factor in retail business performance.

In order to investigate the correlation between long-term provisions and the net profit, the data from the website of the Business Registers Agency of the Republic of Serbia were used to illustrate the companies' business operations. The analysis included the first 100 companies from the list of the most successful enterprises by the net profit in 2017 . Not taking into account the other factors, such an analysis should indicate whether the presence of long-term provisions can be connected to business performance. The results of the correlation analysis are given in Table 1.

According to the significance level of 0.000 , it can be noted that there is a positive correlation between the observed variables. The value of the Pearson correlation coefficient of 0.472 shows that this relationship is moderate (Cohen, 1988), but certainly statistically significant, which confirms the assumption that long-term provisions can be a useful controlling mechanism when the costs of external failure are concerned in terms of the protection of a company's net profit.
Table 1 The Pearson correlation coefficient

\begin{tabular}{llcc}
\hline & & $\begin{array}{c}\text { Long term } \\
\text { provisions }\end{array}$ & $\begin{array}{c}\text { Net } \\
\text { profit }\end{array}$ \\
\hline & $\begin{array}{l}\text { Pearson } \\
\text { Correlation } \\
\text { provisions }\end{array}$ & 1.000 & $.472^{* *}$ \\
& Sig &. & .000 \\
& $\mathrm{~N}$ & 100 & 100 \\
\hline $\begin{array}{l}\text { Net } \\
\text { profit }\end{array}$ & $\begin{array}{l}\text { Pearson } \\
\text { Correlation }\end{array}$ & $.472^{* *}$ & 1.000 \\
& Sig & .000 &. \\
\hline$* *$ Correlation & $\mathrm{N}$ & 100 & 100 \\
\hline
\end{tabular}

Source: Authors

Bearing in mind the fact that in the group of the top 100 most successful enterprises large companies dominate, the difference in the trend is analyzed by the categories: large, medium-sized and small enterprises on the basis of the data from the published financial statements of the Business Registers Agency in the period from 2006 to 2017 (Table 2) in order to obtain the picture of the trend in the enterprises' allocation for long-term provisions (among other things, to cover the costs within the guarantee period).

The small and medium-sized enterprises had approximately the same dynamics of the long-term provisions in the observed period. The biggest relative change compared to the first year occurs in the small enterprises, which also had the highest average annual change in long-term resilience. Namely, in these enterprises, the long-term provisions increased at an average rate of $24.18 \%$ per annum. The mediumsized enterprises recorded a slightly lower average annual change (21.27\%), whereas the smallest relative change was recorded in the large enterprises, where the average annual rate was $10.75 \%$. 
Table 2 Relative changes in long-term provisions (in \%), 2006-2017.

\begin{tabular}{cccc}
\hline Year & Small & Medium & Large \\
\hline 2006. & - & - & - \\
2007. & $41.98 \%$ & $30.99 \%$ & $28.68 \%$ \\
2008. & $3.10 \%$ & $36.41 \%$ & $35.26 \%$ \\
2009. & $112.41 \%$ & $-0.91 \%$ & $26.92 \%$ \\
2010. & $46.18 \%$ & $11.38 \%$ & $7.38 \%$ \\
2011. & $39.40 \%$ & $1.73 \%$ & $2.06 \%$ \\
2012. & $-25.08 \%$ & $35.35 \%$ & $23.83 \%$ \\
2013. & $38.13 \%$ & $3.00 \%$ & $12.37 \%$ \\
2014. & $-16.49 \%$ & $88.31 \%$ & $-23.31 \%$ \\
2015. & $-3.77 \%$ & $17.49 \%$ & $3.09 \%$ \\
\hline 2016. & $24.24 \%$ & $8.36 \%$ & $18.33 \%$ \\
2017. & $5.86 \%$ & $1.90 \%$ & $-16.42 \%$ \\
\hline Change & $593.05 \%$ & $583.25 \%$ & $163.43 \%$ \\
\hline 2017/2006 & $24.18 \%$ & $21.27 \%$ & $10.75 \%$ \\
\hline $\begin{array}{c}\text { Average annual } \\
\text { change }\end{array}$ & & & \\
\hline & & &
\end{tabular}

Source: Authors

However, the variance analysis showed that there is no statistically significant difference between the rate of change in the long-term provisions (the significance level being 0.524) in the observed enterprises in terms of the size (Table 3).

\section{CONCLUSION}

The importance of the costs of non-quality, and among them especially the costs of external failure, is not only in the period of their occurrence and regarding their size, but also in the consequences that can be caused by their emergence. From customers' points of view, a lack of quality can lead to a failure in a company's business. The costs of external failure arise from the return of products, servicing, reclamations and other interventions aimed at dissatisfied consumers. When non-availability costs are incurred, long-term provisions are activated, the function of which is to reduce the consequences. Therefore, long-term provisions appear as an instrument for the protection from the risks of returned products. As an efficient instrument, they can cover all, or part of the costs arising from returned products. The company is able to respond to complaints, which stops a further reaction of dissatisfied consumers, which would arise if such products were not replaced within the warranty period. When a company is able to replace such products within the warranty period and respond to customer interventions, it can continue its business without any delay. With the help of longterm loans, an enterprise covers the costs incurred and does not incur losses. In this way, a company also influences a reduction in the costs of external failure. Based on earlier guarantees, an enterprise has the right to reserve advanced assets and to secure itself from risks. By managing long-term recessions, a company reduces the consequences caused by the discernment of consumers' inefficiencies, quickens the problem and does not do business at a loss. On the other hand, the consumer is satisfied because there was a timely intervention that met his/her demands.

Table 3 ANOVA

\begin{tabular}{lccccc}
\hline & Sum of Squares & df & Mean Square & $F$ & Sig. \\
\hline Between Groups & 1099.123 & 2 & 549.561 & .660 & .524 \\
Within Groups & 24989.945 & 30 & 832.998 & & \\
Total & 26089.068 & 32 & & & \\
\hline
\end{tabular}

Source: Authors 
An effective tool for managing non-quality costs is still being sought. However, based on the research and the authors' conclusions, it can be said that longterm reservations can be a relevant mechanism for managing the costs of external failure as part of the total cost of quality.

In modern business conditions, there is a need to monitor the costs of quality management, especially the costs of external failure, bearing in mind the fact that these costs show a tendency to grow (Anđelković Pešić, 2009). Based on the abovesaid, it is clear that the consequences of a lack of quality are negative. The best argument is that claims do not reflect the true picture of a particular company and create a "halo" effect. This creates a suspicion of the company's business. As the controlling instruments treated as the most sensitive balance sheet, long-term provisions cause a change in costs and affect the financial result. If an entity does not reserve assets, it assumes too much risk to absorb big unnecessary costs, which makes it difficult for it to survive on the market today. The paper emphasizes the fact that the higher amounts of long-term provisions can enable a company to reduce the consequences and manage the costs of external failure, and that long-term provisions can improve a company's business. By highlighting the role of longterm provisions, the awareness of the importance of controlling in the functioning of the company grows.

The introduction of long-term provisions in the field of quality management is aimed at examining the significance of reservation as a mechanism for monitoring and covering the costs of external failure, but also to lay the foundations for further research. Namely, the elimination of non-quality costs before products start being used by consumers is not feasible for every company. For this reason, it is necessary to reduce any potential consequences that may arise from a lack of quality. The paper answers the following questions: does the long-term provision provide security against the risk of external failure costs? Does the management of long-term provisions reduce the consequences resulting from a lack of the quality of a product?
The results of the work done show that long-term provisions are a significant tool for managing the costs of external failure. The initial assumption is that long-term provisions can be an effective tool for managing the cost of quality. The paper analyzes the long-term provisions and the net profit of the first 100 companies on the list of the most successful ones regarding the net profit in the Republic of Serbia in 2017. The results of the correlation analysis show a positive, statistically significant correlation between the long-term provisions and the net profit of the companies. The average annual change in the long-term provisions is the greatest in the small enterprises. The smallest relative change in the longterm provisions in the observed time period (20062017) was recorded in the large enterprises, where the average annual rate was $10.75 \%$, which shows that large enterprises give more importance to long-term provisions compared to medium-sized and small ones.

Having in mind the foregoing, it is necessary to affirm the estimation of long-term provisions which will not depend on the length of the business of the company, but will be related to the risk of doing business in an industry. The analysis presented in the paper is also of a public interest because it contributes to an increase in caution and the significance of a real estimate of longterm provisions. To tell the truth, there is no perfect financial reporting, not only in developing countries, but in the countries of developed economies, either. Simply, the business life of each entity is complex and implies a set of the variables that must be considered. Therefore, it is most important that we should be aware of the negative side of the costs of external failure, which will increase prudence in assessing the amount of long-term provisions.

One of the constraints in the implementation of the research study is a relatively small number of studies on long-term provisions in the context of their impact on external failure management. The limitation of the conducted research is also the insufficient transparency of the balance of a sufficient number of enterprises necessary for the implementation of the appropriate empirical analysis. Also, the lack of the data on long-term provisions for costs in 
the warranty period makes the link between this category of long-term provisions and the net profit impossible to examine, which would provide a clearer picture of the link between these variables and the impact of long-term provisions in terms of providing protection against the external financial result of a company. An analysis of the observed enterprises' balance, based on which the general conclusions on long-term provisions have been made in the study, is not sufficient to declare the sample representative, and the results of the empirical research study are statistically significant, but the sample can certainly be considered as informative, and the analysis is the basis for further research. Finally, the authors believe that a more complete empirical research study could provide a clearer picture of this mechanism, which would certainly contribute to its importance for managing the costs of external failure.

\section{ENDNOTES}

1 Commercial law until IV Directive of the European Economic Community provides a possibility of recognizing provisions for costs incurred in the past year. For example, provisions for the capacity maintenance were made for major repairs, etc.

2 In earlier accounting laws in Serbia, the following provisions could be made: a provision for investment maintenance costs, a flat-rate provision for covering dubious claims, the risk provisions based on the growth of retail prices and foreign exchange rates, the provisions based on revaluation gains, provisions for deferred negative goodwill, etc.

\section{REFERENCES}

Agencijaza privredneregistre RepublikeSrbije,Makroekonomska saopštenja 2006-2017. godine. Retrieved Oktober 21, 2018, from www.apr.gov.rs/Регистри /Финансијскиизвештаји/ Макроекономскасаопштења.аspx

Ali, H., Arif, W., Pirzada, D., Khan, A., \& Hussain, J. (2012). Classical model based analysis of cost of poor quality in a manufacturing organization. Journal of Business Management, $6(2), 670-680$.
Amberkar, S., \& Jagtap, M. M. (2014). Warranty cost modelling and analysis. International Journal of Scientific \& Engineering Research, 5(12), 40-44.

Anđelković Pešić, M. (2009). Modeli upravljanja troškovima kvaliteta. Računovodstvo, Jul-Avgust, 64-75.

Baiman, S., Fischer, P., \& Rajan, M. (2000). Information, contracting, and qualitiy costs. Management Science, 46(6), 776789. doi:10.1287/mnsc.46.6.776.11939

Bamford, D., \& Land, N. (2006). The application and use of the paf quality costing model within a footwear company. International Journal of Quality \& Reliability Management, 23(3), 265-278. doi.org/10.1108/02656710610648224

Barbará, C., Eutrópio, C., de Souza, E., \& Catunda, R. (2008). Modeling the cost of poor quality. WSC 08 . Proceedings of the 40th Conference on Winter Simulation, 1437-1441.

Bisgaard, S. (2007). Quality management and jurans legacy. Quality and Reliability Engineering International, 23(6), 665-677. doi:10.1002/qre.860

Bošković, G. i Anđelković Pešić, M. (2011). Upravljanje kvalitetom osnova konkurentnosti preduzeća i privrede. Niš, Republika Srbija: Ekonomski fakultet Univerziteta u Nišu.

Brandt, L., Biesebroeck, J. V., \& Zhang, Y. (2012). Creative accounting or creative destruction? Firm-level productivity growth in Chinese manufacturing. The National Bureau of Economic Research, NBER Working Paper No. 15152.

Campanella, J. (1999). Principles of quality costs: Principles, implementation, and use. Annual Quality Congress Proceedings, 53(0), 507-508.

Chatzipetrou, E., \& Moschidis, O. (2016). Quality costing: A survey in Greek supermarkets using multiple correspondence analysis. International Journal of Quality \& Reliability Management 33(5), 615-632. doi.org/10.1108/IJQRM-01-2014-0004

Chi Tsou, J. (2007). Economic order quantity model and Taguchi's cost of poor quality. Applied Mathematical Modeling, 31(2), 283291. doi.org/10.1016/j.apm.2005.11.007

Cohen, J. (1988). Statistical Power Analysis for the Behavioral Sciences. (2nd ed.). Hillsdale, NJ: Lawrence Erlbaum Associates, Publishers.

Đukić, T., \& Pavlović, M. (2014). Creative accounting and cash flows reporting. Facta Universitatis-Economics and Organization, 11(3), 227-235. 
Eben-Chaime, M. (2013). A note on: The economic effects of quality improvements. Total Quality Management $\mathcal{E}$ Business Excellence, 24(3-4), 374-377.

Feigenbaum, A. V. (1994). Controle da qualidade total: Gestão e sistemas. São Paulo, Brazil: Makron Books.

Fu, F., \& Zhang, T. (2016). A new model for solving time-costquality trade-off problems in construction. PLOS ONE 11(12), e0167142, doi.org/10.1371/journal.pone.0167142

IAS 37 - Резервисања, потенцијалне обавезе и потенцијална имовина. IFRS, Retrieved Oktober 13, 2018, from https://www. ifrs.org/.

Krishnan, S., Agus, A., \& Husain, N. (2000). Costs of quality: The hidden costs. Total Quality Management, 11(4-6), 844-848. doi:10.1080/09544120050008309

Krstić, B., Anđelković Pešić, M., \& Anđelković, A. (2010). Managing the variations in time, quality of realization and outputs of activities with the aim of encreasing efficiency of business process. Economic Themes, 48(3), 345-354.

Lukić, R. (2014). Utjecaj povrata roba na performanse $\mathrm{u}$ maloprodaji. Ekonomski pregled 65(1), 89-104.

Lukić, R. (2017). The impact of long-term provision costs on performance of trade in Serbia. Economic and Environmental Studies, 17(3), 455-474. doi: 10.25167/ees.2017.43.1

Malinić, D. (2009). Savremeni izazovi integralnog istraživanja kvaliteta finansijskih izveštaja. Ekonomika preduzeća, 57(3-4), 138-155.

Malmi,T.,Järvinen,P.,\&Lillrank,P.(2004). Acollaborativeapproach for managing project cost of poor quality. European Accounting Review, 13(2), 293-317. doi:10.1080/0963818042000204733

Mamer, J. (1987). Discounted and per unit costs of product warranty. Management Science, 33(7), 916-930.

Maronick, T. (2007). Consumer perceptions of extend warranties. Jorunal of Retailing and Consumer Sevices, 14(3), 224-231. doi:10.1016/j.jretconser.2006.09.003
Raupp, F. M., \& Gaebler, D. M. (2016). Identification and measurement of quality costs and non quality in a textile and apparel industry. Systems \& Management, 11, 282-289. doi:10.20985/1980-5160.2016.v11n3.1104

Sailaja, A., Basak, P., \& Viswanadhan, K. (2015). Hidden costs of quality: Measurement \& analysis. International Journal of Managing Value and Supply Chains (IJMVSC), 6(2), 13-25. doi:10.5121/ijmvsc.2015.6202.

Satanova, A., \& Sedliacikova, M. (2015). Model for controling the total costs of quality. Procedia-Economics and Finance. 26, 2-6.

Schiffauerova, A., \& Thomason, V. (2006). A review of research on cost of quality models and best practices. International Journal of Quality and Reliability Management, 23(4), 1-23. doi:10.1108/02656710610672470

Teli, S. N., Majali, V., Bhushi, U., \& Surange, V. (2012). Assessment of cost of poor quality for automobile industry. International Journal of Engineering Research and Applications, 2(6), 330-336.

Teli, S. N., Majali, V. S., Bhushi, U., \& Surange, V. G. (2014). Impact of poor quality cost in automobile industry. International Journal of Quality Engineering and Technology, 4(1), 1757-2185. doi:10.1504/IJQET.2014.059842.

Vučićević, V., \& Anđelković Pešić, M. (2012). Quantification of quality: The iddicators of justification of the improvement of processes and product quality. Facta Universitates - Economics and Organization, 9(4), 495-506

Wojtaszek, H. (2015). Role of managerial accounting in the innovative enterprise. World Scientific News (WSN), 57(2016), 652-658

Xie, W. (2017). Optimal pricing and two-dimensional warranty policies for a new product. International Journal of Production Research, 55(22), 6857-6870. doi.org/10.1080/00207543.2017.1355 578 
Received on $12^{\text {th }}$ November 2018, after revision, accepted for publication on $17^{\text {th }}$ April 2019

Published online on $25^{\text {th }}$ April 2019

Milica Ristic is a $\mathrm{PhD}$ student at the Faculty of Economics, University of Nis. The key areas of her research interests are: public finance, fiscal policy, financial reporting and banking.

Radenko Milojevic is a full professor at the Faculty of Economics, University of Nis. He obtained his $\mathrm{PhD}$ at the Faculty of Economics in Subotica, University of Novi Sad. He teaches the courses: Enterprise resource management, Management of human resources, Agency business, International management of human resources, Business processes management, Career management, Business decision making costs. The key areas of his research interest are: business functioning, human resources management, and business processes management.

Marija Radosavljevic is an associate professor at the Faculty of Economics, University of Nis. She obtained her PhD at the Faculty of Economics, University of Belgrade. Key areas of her research interest includes: quality management, business processes management, cost management, human resources management. 


\title{
DUGOROČNA REZERVISANJA KAO MEHANIZAM OBEZBEĐENJA USLED IZOSTANKA KVALITETA
}

\author{
Milica Ristić, Radenko Milojević i Marija Radosavljević \\ Ekonomski fakultet Univerziteta u Nišu
}

\begin{abstract}
Savremeni uslovi poslovanja decidirano ukazuju na to da je kvalitet osnova konkurentnosti preduzeća. Izostanak kvaliteta stvara nezadovoljstvo i utiče negativno na lojalnost kupaca. U poslednje vreme, dolazi do tendencije rasta troškova, koji su posledica izostanka kvaliteta isporučenih proizvoda. Iako se u brojnim radovima nalaze modeli za obračun troškova nekvaliteta, nije pronađen relevantan mehanizam za upravljanje ovim troškovima. U ovom radu, autori su pokušali da pronađu vezu između dugoročnih rezervisanja i troškova eksternih otkaza, kojom se bavi mali broj istraživača. Cilj istraživanja je da se ukaže na značaj dugoročnih rezervisanja, koja mogu biti relevantan instrument kontrolinga u upravljanju troškovima eksternih otkaza. U tom smislu, rad je komponovan tako da se, najpre, daje pregled literature koja se tiče upravljanja troškovima kvaliteta, zatim, dugoročnih rezervisanja i, na kraju, uspostavlja veza između dugoročnih rezervisanja i troškova eksternih otkaza. Istraživanje je potvrdilo polaznu pretpostavku, odnosno, pokazalo je da su dugoročna rezervisanja efikasan instrument upravljanja troškovima eksternih otkaza. Takođe, na primeru podataka prvih 100 preduzeća, na listi najuspešnijih u Republici Srbiji u 2017, identifikovana je pozitivna, statistički značajna korelacija između dugoročnih rezervisanja i neto dobitka preduzeća.
\end{abstract}

Ključne reči: kvalitet, troškovi kvaliteta, troškovi eksternih otkaza, dugoročna rezervisanja

JEL Classification: L52, M21, M41

\section{UVOD}

Konkurencija, koja na tržištu propulzivno deluje čak i na mala preduzeća, nameće uslov svim učesnicima da ne mogu da opstanu bez efikasnog finansijskog i ekonomskog upravljanja. Ambicija preduzeća je da posluju u skladu sa zahtevima tržišta, da "prežive“"

* Korespondencija: M. Radosavljević, Ekonomski fakultet Univerziteta u Nišu, Trg Kralja Aleksandra Ujedinitelja 11, 18000 Niš, Republika Srbija;

e-mail: marija.radosavljevic@eknfak.ni.ac.rs na tržištu, povećavaju svoju finansijsko-ekonomsku efektivnost, i razvijaju se (Eben-Chain, 2013).

Filozofija poslovanja u savremenim uslovima naglašava značaj kvaliteta, kao jedan od važnih faktora uspeha poslovanja preduzeća. „Premda se o njemu intenzivnije govori i piše tek poslednjih nekoliko decenija XX-og veka, kvalitet je imanentan ljudskoj prirodi, te se može reći da je "stariji“ od preduzeća" (Bošković i Anđelković Pešić, 2011, 2). Međutim, treba imati u vidu da je kvalitet, ili skup atributa proizvoda 
koji su neophodni da bi se zadovoljile potrebe kupaca, promenljive prirode. Stoga je, u cilju kontrole kvaliteta proizvoda/usluga, neophodno da preduzeće deluje reaktivno ili proaktivno (Vučićević i Anđelković Pešić, 2012). Reaktvno delovanje preduzeća uključuje aktivnosti koje su usmerene prema nezadovoljnim kupcima. Proaktivno delovanje obuhvata aktivnosti koje preduzeće preduzima da bi sprečilo nastanak defekata i pojavu nezadovoljnih kupaca. Skup svih aktivnosti reaktivnih i proaktivnih postupaka preduzeća dobija posebnu pažnju u akademskim krugovima. Preduzeća sve više počinju da se bave pitanjima kontrole kvaliteta, gledajući na kvalitet kao na faktor konkurentske prednosti. Analogno, upravljanje troškovima kvaliteta postaje imperativ nove ekonomije.

Iako u literaturi postoje brojne klasifikacije troškova kvaliteta, većina autora je prihvatila strukturu troškova kvaliteta koju je dao A. V. Feigenbaum (1994). Prema ovom autoru, troškovi kvaliteta se mogu podeliti na troškove prevencije, troškove detekcije, troškove internih otkaza, i troškove eksternih otkaza. Troškovi prevencije nastaju kao rezultat aktivnosti koje imaju za cilj da spreče potencijalni izostanak kvaliteta i mogućnost da neusaglašeni proizvodi stignu do kupaca. Troškovi detekcije nastaju sa naporima preduzeća da u cilju zadovoljenja zahteva potrošača, utvrdi stepen usaglašenosti proizvoda sa zahtevima za kvalitet. Kontrola kvaliteta dobija svoju pažnju, upravo zbog troškova koji nastaju da bi se utvrdilo da li se održava odgovarajući kvalitet. Međutim, globalizacija i sve veći zahtevi potrošača, onemogućili su da preduzeća upravljaju samo ovim troškovima kvaliteta. Primećuje se rast troškova internih i eksternih otkaza. Zbog toga se ovi troškovi nazivaju troškovi nekvaliteta/otkaza. Troškovi nekvaliteta nastaju kada je stvoren proizvod neodgovarajućeg kvaliteta. Kao takvi, predstavljaju „razliku između stvarnih operativnih troškova i operativnih troškova koji bi nastali da nije bilo neuspeha u sistemima preduzeća od strane zaposlenih" (Krishnan, Agus \& Husain, 2000, 844). Troškovi internih otkaza nastaju kada proizvođač otkrije grešku u toku sklapanja proizvoda, dok troškovi eksternih otkaza nastaju kada kupac proizvoda otkrije grešku.
Troškovi internih otkaza uključuju: troškove analize defekata, troškove zamene, troškove tretmana i popravki, troškove ponovnog pregleda i testiranja, troškove eliminisanja proizvoda sa defektom, oportunitetne troškove, troškove otpada. Troškovi eksternih otkaza uključuju troškove povlačenja proizvoda sa tržišta, troškove koji nastaju usled izgubljene prodaje, troškove vraćenih proizvoda sa garantnim rokom, troškove transporta koji nastaju usled vraćenih proizvoda, troškove servisiranja proizvoda (Vučićević i Anđelković Pešić, 2012, 498). Troškovi eksternih otkaza su rezultat nezadovoljnih potrošača, koji stavljaju reklamaciju na proizvod nezadovoljavajućeg kvaliteta i traže intervencije $u$ garantnom roku, ili vraćaju isti. Ovi troškovi mogu ostaviti posledice na poslovanje preduzeća, ukoliko preduzeće nema dovoljno sredstava da obezbedi nove proizvode u garantnom roku.

Predmet istraživanja su troškovi kvaliteta, odnosno, troškovi eksternih otkaza, koji se javljaju usled izostanka kvaliteta, očekivanog od strane potrošača. Cilj istraživanja je da se ukaže na značaj i ulogu dugoročnih rezervisanja za upravljanje troškovima kvaliteta, pri čemu se polazi od pretpostavke da dugoročna rezervisanja mogu biti posebno efikasan alat za upravljanje troškovima eksternih otkaza. Identifikovanje troškova eksternih otkaza i obezbeđenje za slučaj njihovog javljanja veoma je značajno, jer je kvalitet, sasvim izvesno, jedan od zahteva potrošača uz vreme isporuke, cenu i fleksibilnost proizvoda, koji predstavljaju ključne konkurentske prioritete u savremenim uslovima (Krstić, Anđelković Pešić i Anđelković, 2010, 346).

Samom orijentacijom na izučavanje dugoročnih rezervisanja, ovo istraživanje upućuje na primenu šireg spektra metoda istraživanja. Ovom istraživanju primereno je korišćenje metoda indukcije, koji je upotrebljen za analizu svih troškova kvaliteta i donošenje opštih zaključaka. Metod analize i metod sinteze upotrebljeni su za analizu dugoročnih rezrvisanja. Primenjen je istorijski metod i metod kompilacije, kojim je pristupljeno analizi drugih istraživanja iz ove oblasti, kao odgovarajući metodi statističke analize (korelaciona analiza i analiza varijanse). Testiranje postavljene hipoteze, vršeno je desk metodom, koja podrazumeva korišćenje stručne i naučne literature. 
U istraživanju se pošlo od pretpostavke da su dugoročna rezervisanja efikasan instrument upravljanja troškovima eksternih otkaza, te da između dugoročnih rezervisanja i neto dobitka preduzeća postoji pozitivno kvantitativno slaganje, odnosno, pozitivna korelacija. Imajući u vidu prirodu dugoročnih rezervisanja, očekuje se da će navedena pretpostavka, kroz proces testiranja, biti potvrđena.

$\mathrm{U}$ prvom delu rada dat je pregled literature o troškovima kvaliteta i dugoročnim rezervisanjima. Drugi deo rada analizira ulogu dugoročnih rezervisanja u upravljanju troškvima. U trećem odeljku ispituje se da li dugoročna rezervisanja mogu biti efikasan alat za smanjenje posledica neadekvatnog kvaliteta. Četvrti deo sadrži zaključke.Na osnovu dobijenih rezultata, očekuje se koncipiranje smernica za dalja istraživanja. Rad nastoji da afirmiše dobru procenu dugoročnih rezervisanja, u cilju zaštite od savremenih rizika poslovanja.

\section{UPRAVLJANJE TROŠKOVIMA KVALITETA}

Koncept kvaliteta se može vezati za pedesete godine XX-og veka i grupu istraživača koju čine Edwards Deming, Joseph Juran i Armand Feigenbaum. Tada je merenje i izveštavanje o troškovima kvaliteta bio prvi korak ka menadžmentu kvaliteta. Vremenom, troškovi kvaliteta postaju „zlatan rudnik“ kompanija i aktuelna tema akademskih krugova. Najveća pažnja bila je posvećena troškovima prevencije, shodno tome da se tada, upravljanjem ovom vrstom troškova, dobro upravljalo kvalitetom. Prema Juranu „kvalitet podrazumeva pogodnost za upotrebu", te je ovaj autor ukazao na veliki značaj troškova prevencije. Njegov model optimalnih troškova kvaliteta, stvorio je osnove za dalja istraživanja na polju troškova kvaliteta (Bošković i Anđelković Pešić, 2011).

Filozofija troškova kvaliteta svoju ekspanziju u akademskim krugovima doživela je nakon 1990-ih. D. Bamford i N. Land (2006) naglašavaju da se analiza troškova kvaliteta može izvršiti najbolje ukoliko se uzmu u obzir svi troškovi kvaliteta. Opširniju analizu troškova kvaliteta, koji doprinose kvalitetu proizvoda i usluga, dali su A. Sailaja, P. Basak i K. Viswanadhan (2015). Njihovi rezultati istraživanja ukazuju na to da postoje skriveni troškovi kvaliteta, koji mogu biti do tri puta veći od poznatih troškova kvaliteta. Međutim, prema stavovima autora, svi troškovi kvaliteta mogu biti smanjeni, ili eliminisani pravilnim praćenjem i razumevanjem osnovnih uzroka.

Bez kvalitetnih proizvoda, preduzeća ne mogu ostvariti očekivanu dobit. Ne samo što greške stvaraju nepotrebne troškove u preduzeću, već i otežavaju proizvodni proces ostavljajući posledice koje mogu dovesti do zaustavljanja proizvodnje (Campanella, 1999). A. Schiffauerova i V. Thomason (2006) su dali pregled objavljene literature o različitim pristupima kvalitetu i uspešnoj primeni tih pristupa, ukazujući na to da pristup troškovima kvaliteta mora odgovarati situaciji, svrsi, potrebama kompanije i okruženju. S. Bisgaard (2007), ukazuje da se na osnovu postojećih radova na temu, ne može dati "savršen" pristup upravljanju troškovima kvaliteta, iako je Juran uspeo da sintetizuje temu i obezbedi koherentan okvir i terminologiju. Juran je predvideo mnoge principe koji su kasnije inkorporirani pod „Six Sigma kišobran“ (Bisgaard, 2007, 665). Takođe, i drugi lideri teorija kvaliteta pružaju značajne metode, tehnike i instrumente, koji ne samo da olakšavaju upravljanje troškovima kvaliteta, već i omogućavaju efikasno upravljanje preduzećem. „Međutim, nijedan pristup ne nudi konkretna rešenja, niti postoji prisup koji bi se mogao smatrati konkretnim rešenjem za konkretno preduzeće" (Bošković i Anđelković Pešić, 2011, 56).

Sve veće učešće u ukupnim troškovima imaju troškovi internih i eksternih otkaza. Prema A. V. Feigenbaum-u (1994), troškovi nekvaliteta predstavljaju 65-70\% ukupnih troškova kvaliteta. Naglašavanje značaja troškova nekvaliteta proizilazi iz njihovog otkrivanja od strane kupaca, koje može značajno uticati na poslovanje preduzeća. Kupac, najvažnija karika u poslovanju preduzeća, nezadovoljan kvalitetom proizvoda, može uticati da preduzeće počne da posluje sa gubitkom. Naime, broj vraćenih proizvoda je $\mathrm{u}$ inverznoj korelaciji sa dobitkom. Ukoliko dođe do povećanja broja reklamacija, otvara se pitanje opstanka preduzeća (Raupp, Gaebler, 2016, 284). 
T. Malmi, P. Järvinen i P. Lillrank (2004), naglasili su da je nemoguće koristiti tradicionalne metodologije kada je reč o upravljanju troškovima nekvaliteta. Autori su u svom istraživanju predstavili pristup upravljanju ovim troškovima. Troškovi eksternih otkaza, shodno savremenim uslovima poslovanja, dobijaju sve veću ulogu u planiranju. Međutim, problem predstavlja to što pojedini troškovi eksternih otkaza nisu uključeni u troškove kvaliteta. Prema tome, stvara se problem upravljanja troškovima eksternog otkaza, za koje se ne zna da li će uopšte nastati. Prema rezultatima istraživačkog projekta, troškovima je moguće upravljati uvođenjem upotrebe perspektivne vrednosti i verovatnoće pojave. Troškovi eksternih otkaza, ili troškovi izostanka kvaliteta, su „svi oni troškovi koji bi nestali ukoliko bi proizvodni proces bio savršen" (Teli, Majali, Bhushi \& Surange, 2012, 330). Troškovi eksternih otkaza nastaju kada kvalitet koji izostane ima direktne implikacije za potrošača. To za posledicu ima određene rizike $u$ poslovanju. Potrošač zahteva reklamaciju proizvoda, intervencije u garantnom roku, vraća proizvod i širi vest o nekvalitetu.

Model koji je koncipirao J. Chi-Tsou (2007), potvrđuje da su defektni proizvodi i troškovi nekvaliteta jedan od faktora za smanjenje profita preduzeća. Promene koje su uzrokovane neispravnim proizvodima, utiču na smanjenje godišnjeg profita. H. Ali, W. Arif, D. Pirzada, A. Khan i J. Hussain (2012), u svojoj studiji su se fokusirali na troškove nekvaliteta proizvodne jedinice u Pakistanu, analizirajući troškove internih i eksternih otkaza. Autori daju model koji ima za cilj da minimizira i eliminiše troškove otkaza, uključujući i troškove koji su nastali zbog garancija. U suštini, najvažnija stvar u smanjenju troškova nekvaliteta je postaviti prioritete za efektivno korišćenje resursa, a to može biti realizovano identifikovanjem faktora koji doprinose nastanku istih. F. M. Raupp i D. M. Gaebler (2016), identifikuju troškove nekvaliteta, i daju klasifikaciju troškova kvaliteta u periodu 1990 - 2003. Autori su ukazali na značaj njihovog istraživanja sa akademske tačke gledišta, zbog oskudnih radova iz ove oblasti. Rezultati istraživanja ukazuju da troškovi nekvaliteta prevazilaze troškove kvaliteta.
„Onde gde postoji potreba za kontrolom nečega, prva stvar koju treba uraditi je mera. Ako nešto nije kvantitativno izraženo, ne možemo njime upravljati i kontrolisati ga" (Krishnan, Agus \& Nooreha, 2010, 844). Teško je predvideti troškove eksternih otkaza, jer zavise od vrste industrije, nivoa implementacije upravljanja kvalitetom, ali i mnogih drugih faktora. Stoga, izučavanje mehanizama koji omogućavaju realnu procenu troškova nekvaliteta, ima veliki značaj.

Na značaj identifikovanja i analize troškova eksternih otkaza, ukazuje i negativna korelacija između ukupnih troškova upravljanja kvalitetom i troškova internih i eksternih otkaza (Slika 1). Za razliku od drugih vrsta troškova kvaliteta, sa opadanjem nivoa kvaliteta, ovi troškovi rastu. U zoni opadanja ukupnih troškova kvaliteta, učešce troškova internih i eksternih otkaza u ukupnim troškovima kvaliteta značajno se povećava.

Prema nekim autorima (Fu \& Zhang, 2016), najvažniji troškovi su oni koji se javljaju u fazi upotrebe proizvoda, odnosno, troškovi koji prate postproizvodni proces. Ovi troškovi involviraju upravo troškove kvaliteta u garantnom roku, troškove servisiranja proizvoda, i troškove održavanja proizvoda, odnosno, troškove eksternih otkaza.

S. Baiman, P. Fischer i M. Rajan (2000), analizirali su odnos kvaliteta proizvoda i troškova kvaliteta. Ispitali su uspeh inkorporiranja specijalnog informacionog sistema, koji bi smanjio neefikasnost i troškove eksternih otkaza. S. N. Teli et al (2014), sprovode eksperimentalno istraživanje na polju automobilske industrije. $U$ cilju ispitivanja profitabilnog upravljanja poslovanjem, autori vrše procenu tržišno orijentisanih aspekata troškova kvaliteta. "Praćenje troškova nekvaliteta bi pomoglo analiziranju operativnih troškova" (Teli et al, 2014, 1757). Na osnovu prikupljenih podataka, autori vrše grafičku analizu uticaja troškova kvaliteta na poslovanje preduzeća. Jednu od tehnika za smanjenje troškova nekvaliteta analiziraju C. Barbará, C. Eutrópio E. de Souza i R. Catunda (2008). Analizirali su neproizvodne troškove, probleme neusaglašenosti, neuspeh uslužnih delatnosti i gubitak prihoda zbog nedostatka kvaliteta. Smatra se da kontrola kvaliteta 


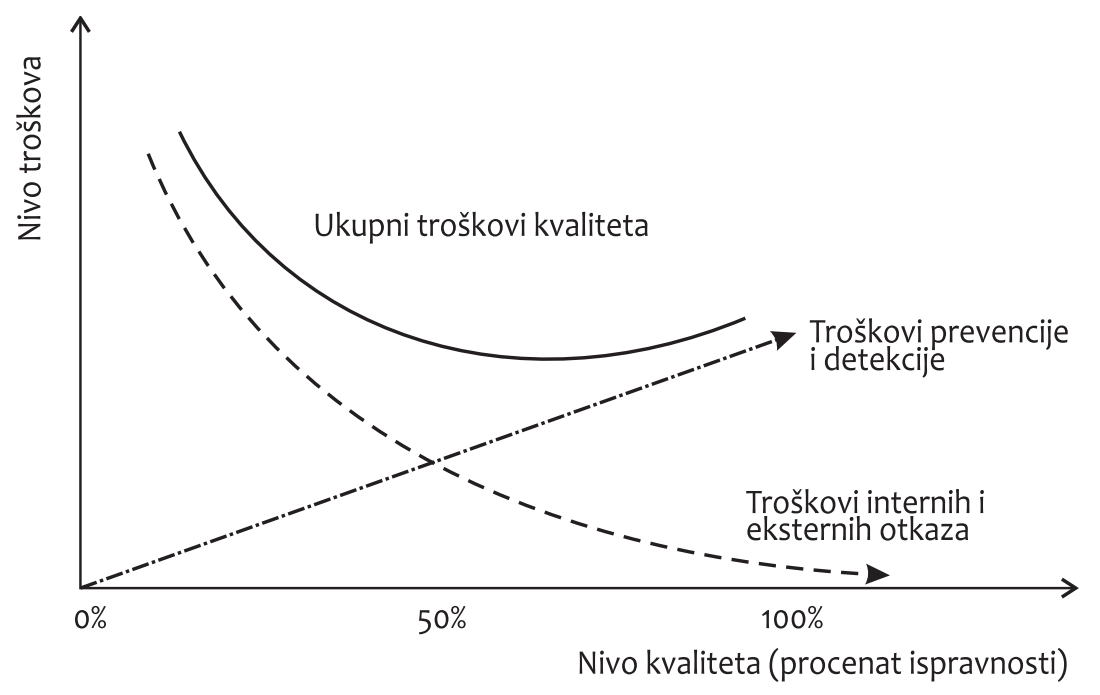

Slika 1 Kretanje troškova kvaliteta

Izvor: Bošković i Anđelković Pešić, 2011, 171.

treba početi u fazi dizajniranja proizvoda (Bošković i Anđelković Pešić, 2011). Međutim, i pored pozitivnih efekata takve kontrole, ona se čini nedovoljnom $\mathrm{u}$ savremenim uslovima poslovanja. Uzimajući to u obzir, V. Vučićević i M. Anđelković Pešić (2012), ispituju posledice izostanka kvaliteta i ukazuju na značaj kontrole. Kontroling, kao važnu determinantu poslovanja preduzeća, ispitivali su i A. Satanova i M. Sedlicikova (2015). Fokusirajući se na brigu o kontroli troškova nekvaliteta, naglasili su da je kontrola i upravljanje troškovima povezano sa principima TQM filozofije. Konačno, „kontroling pruža okvir za primenu statističke kontrole kvaliteta, dizajniranje eksperimenata, poboljšanje kvaliteta, kao i primenu metoda pouzdanosti“ (Bisgaard, 2007). To upućuje na potrebu analize povezanosti upravljanja troškovima kvaliteta i kontrolinga, odnosno, ispitivanje uloge kontrolinga i odgovarajućih instrumenata u procesu upravljanja troškovima kvaliteta.

\section{DUGOROČNA REZERVISANJA KAO INSTRUMENT KONTROLINGA}

Kontroling predstavlja dobar način upravljanja sa aspekta računovodstva, koji je neophodan da bi se sačuvale osnove kontrole (Wojtaszek, 2016). Neophodan je za procenu procesa upravljanja, tačnije, $\mathrm{u}$ oceni finansijskih rezultata, sa posebnim fokusom na analizu troškova. Kao jedan od instrumenata kontrolinga, koji se koristi u zaštiti od rizika poslovanja, izdvajaju se dugoročna rezervisanja.

Još se u Francuskoj i Nemačkoj šezdesetih godina XX-og veka godina videla široka lepeza izdvajanja za raznovrsne rizike. Rezervisanja su involvirala rezervisanja za sporove, za date garancije kupcima, za kazne i penale, za gubitke na kursevima, za učešće radnika u efektima razvoja, za rabate, za razlike $\mathrm{u}$ porezima, pa čak i penzije, godišnje odmore. Sve ovo ukazuje na značaj rezervisanja za funkcionisanje preduzeća.

Dugoročna rezervisanja pripadaju pozajmljenom kapitalu. Kao kategorija pozajmljenog kapitala, predstavljaju specifičnu obavezu egzaktnog karaktera, i po tome se razlikuju od ostalih stavki pozajmljenog kapitala. Obaveza podrazumeva sadašnju obavezu koja je proistekla iz prethodnog događaja (činom prodaje, preduzeće se obavezuje da će realizovati određene aktivnosti za koje je dalo garanciju kupcu, pri čemu te aktivnosti nastaju za nekoliko godina). Izmirenje nastale obaveze će dovesti do odliva tačno određenih resursa preduzeća. Kod rezervisanja, 
na dan bilansa, ne može se znati tačan iznos i tačan rok dospeća obaveze (reklamacija), po čemu se rezervisanja razlikuju od ostalih obaveza. Dugoročna rezervisanja su obaveze koje se ne vrednuju na osnovu dokumenta, već se njihovo vrednovanje vrši na osnovu procene. Dugoročna rezervisanja se razlikuju i od potencijalnih obaveza. Rezervisanje je obaveza koja postoji na dan bilansa stanja, a potencijalna obaveza nije sadašnja i ona ne postoji na dan bilansa stanja. Potencijalna obaveza je moguća obaveza. Prema Međunarodnom računovodstvenom standardu IAS 37 (paragraf 10), „rezervisanje obaveza sa neizvesnim rokom dospeća ili iznosom" (IAS 37, 2009, 16), je sadašnja obaveza preduzeća proistekla iz prošlog događaja, po osnovu koje će doći do odliva ekonomskih koristi iz preduzeća. Ukoliko nema prošlog događaja, nema obligacionog odnosa koji stvara obavezu, pa nema ni rezervisanja.

Dakle, da bi se izvršilo rezervisanje, neophodno je ispuniti dva uslova:

- obaveza postoji na dan bilansa, tj. postoji obligacioni odnos zasnovan na zakonu ili običaju,

- visina i rok obaveze nisu poznati, postoji velika neizvesnost (rezervisanja su neizvesnija čak i od pasivnih vremenskih razgraničenja), ali je, opet, nužno postojanje dovoljno izvesnog očekivanja stvarnog nastanka.

Prošli događaj može da kreira dve vrste obaveza: legalnu obavezu, i konstruktivnu obavezu. Legalna obaveza nastaje iz nekog ugovora, zakonodavno, ili po osnovu sile zakona, na primer, sudska odluka. Konstruktivna obaveza nastaje po osnovu nekih aktivnosti entiteta, a za koju on zna da će nastati iz prakse ili iz neke izjave o prihvatanju neke odgovornosti. ${ }^{1} \mathrm{U}$ suštini, nema razlike između rezervisanja kreiranih na osnovu legalnih ili konstruktivnih obaveza, prati ih isti računovodstveni tretman. Prepoznavanje da li se radi o legalnoj ili konstruktivnoj obavezi ukazuje na vreme kada se priznaje rezervisanje.

Osnov za rezervisanje daju načelo uzročnosti prihoda i rashoda, i načelo opreznosti. Radi se o tome da, ukoliko se ostvari prihod $\mathrm{u}$ tekućem periodu, na primer, po osnovu prodaje neke robe, logično je da će doći do rashoda po osnovu izdavanja te robe, koji će nastati u budućem periodu kao posledica prihoda tekućeg perioda. Ti rashodi će se priznati kao rashodi tekućeg perioda. Uključivanjem takvih rashoda $\mathrm{u}$ bilansnu poziciju Dugoročna rezervisanja, praćeno je uvek povećanjem rashoda $\mathrm{u}$ Bilansu uspeha i smanjenjem periodičnog rezultata. Takođe, ako su prihodi veći od rashoda, rezervisanja će biti pokrivena prihodima i pojaviće se $u$ vidu likvidnih sredstava $u$ aktivi Bilansa stanja. Do momenta isplate rashoda po osnovu kojih su i osnovana rezervisanja, sredstava koja potiču iz prihodima pokrivenih rezervisanja mogu se koristiti za finansiranje drugih potreba. Ovde se vide karakteristike pozajmljenog kapitala, jer se rezervisanja u ovom slučaju pojavljuju kao izvori sredstava.

U literaturi i zakonodavstvu, nije data opštevažeća lista rizika, koji su osnova za formiranje rezervisanja. U Francuskoj, rezervisanja predstavljaju posebnu poziciju sopstvenog kapitala. Radi se o obavezama tekućeg i prošlog obračunskog perioda, prema budućim obračunskim periodima. Pravila finansijskog izveštavanja nalažu da se $u$ finansijskim izveštajima troškovi koji nastaju u budućnosti, priznaju u formi rezervisanja u tekućem periodu. Dakle, troškove treba priznati $\mathrm{u}$ perodu u kome su uzrokovani, i ne treba odlagati njihovo priznavanje do trenutka kada oni stvarno nastanu.

Da bi se rezervisanja našla $u$ ulozi upravljanja troškovima nekvaliteta, neophodno je izvršiti procenu istih i „priznati ih“. Priznavanje rezervisanja, prema IAS 37, podrazumeva da su ispunjena tri uslova:

- sadašnja obaveza,

- verovatnoća odliva resursa za izmirenje pomenute obaveze, i

- pouzdana procena obaveze.

Važno je da prošli događaj, prodaja proizvoda, koji je stvorio sadašnju obavezu prema kupcu, ne ostavlja preduzeću drugu alternativu nego da priznatu obavezu izmiri. Verovatnoća odliva resursa je pretpostavka koja opravdava otvaranje računa Dugoročna rezervisanja. 
Najbolja procena obaveze bila bi jednaka izdacima koji su potrebni za izmirenje sadašnje obaveze na dan bilansa stanja. To znači da se u razmatranje moraju uzeti i rizici i događaji koji će tek uslediti. Procenu vrši menadžment preduzeća na osnovu akta preduzeća. Ukoliko preduzeće nije imalo do sada priznata rezervisanja, najbolja procena se vrši na osnovu konkurencije u grani. Svako preduzeće bi trebalo da pitanje rezervisanja razradi aktom, jer od situacije zavisi njihova procena i mogućnost priznavanja.

Shodno kompleksnosti ovog računa, često u praksi biva pogrešno priznavanje, ili nepotrebno priznavanje. Često poslovni gubici bivaju posmatrani kao obaveza. Međutim, oni nemaju prošli događaj i logično je da neće biti dugoročnih rezervisanja. Možemo izbeći buduće poslovne gubitke primenom neke mere da ih spreči ili prodajom dela poslovanja. Da pozicije $\mathrm{u}$ finansijskim izveštajima ne bi bile precenjene ili potcenjene, vrši se procenjivanje imovinskih predmeta po nabavnim cenama, ili po cenama koštanja. Preciznije, finansijski izveštaji se sastavljaju u skladu sa načelom opreznosti. Analogno načelu opreznosti, oslonac proceni dugoročnih rezervisanja treba biti i načelo pouzdanosti, da bi postojala sigurnost da je procena pouzdana. Računovodstveni standard IAS 37 insistira na razumnoj proceni i ukoliko rezervisanje zadovoljava uslove priznavanja, neće se priznati ako je procena u ovom slučaju odliva ekonomskih koristi, nepouzdana.

Angažovanje stručne osobe pri proceni rezervisanja za troškove u garantnom roku ima važnu ulogu. Shodno činjenici da jedino profesionalni računovođa može obezbediti kvalitet finansijskog izveštavanja, isto tako i stručnjaci za procenu dugoročnih rezervisanja mogu obezbediti kvalitetnu i kompetentnu procenu. Takođe, neophodno je da postoji spona između politike računovodstva, politike kvaliteta i politike inžinjera koji će izvršiti procenu. Dakle, neophodno je imati perspektivu ne samo sa apsekta računovođe, već i sa aspekta finansija, marketinga i inžinjeringa. Nakon što se dugoročna rezervisanja procene, svake godine se ponovo razmatra iznos procene i po potrebi vrše određene korekcije. Promene se mogu dogoditi na svaki dan bilansa i ako više nije verovatno da će podmirivanje obaveze zahtevati odliv ekonomskih koristi, rezervisanje treba ukinuti u korist prihoda.
Kreativno finansijsko izveštavanje može ozbiljno da ugrozi upotrebnu vrednost finansijskih izveštaja (Malinić, 2009, 156; Brandt, Biesebroeck \& Zhang, 2012; Đukić i Pavlović, 2014). Politika rezervisanja iziskuje stalna proveravanja i korigovanja, jer se rezervisanja moraju pratiti kontinualno, da bi odrazila najbolju sadašnju procenu. Usled neizvesnosti može se promeniti iznos rezervisanja. Svako korigovanje nosi za sobom ili rashode ili prihode i utiče na rezultat. Empirijskim istraživanjem dugoročnih rezervisanja, opisane su firme koje poboljšavaju svoje performanse povećanjem dugoročnih rezervisanja. Nepravilno iskazan krajnji rezultat može stvoriti pogrešnu sliku kod investitora i preusmeriti ih da ulože sredstva u neko drugo preduzeće. Takođe, može odvratiti poverioce $u$ pogledu davanja kredita ili umanjiti vrednost akcija i dividendi ukoliko dobit bude drastično umanjena. Prema tome, proceni ovog računa treba posveti posebnu pažnju kako bi posledice bile minimizirane.

U pojedinim slučajevima, prilikom procene dugoročnih rezervisanja, efekat novca je značajan, pogotovu ako se radi o vremenskom periodu koji je duži od godinu dana. Rezervisanja, koja se odnose na odlive novca koji će nastati odmah nakon datuma bilansa, su vrednija nego novčani odlivi istog iznosa koji nastaju kasnije. U ovakvim slučajevima, rezervisanja treba diskontovati.

Ukoliko se iznos rezervisanja proceni nerealno i rezervisanja bivaju precenjena, nastaju latentne rezerve, u suprotnom nastaju skriveni gubici. Latentne rezerve smanjuju periodični rezultat poslovanja, jer je došlo do precenjivanja pozicije pasive. Često se latentne rezerve, zbog uticaja na poslovni rezultat definišu kao deo realizovanog dobitka, koji nije iskazan. Suprotna bilansna kategorija latentnim rezervama jesu skriveni gubici, koji nastaju zbog potcenjivanja pasive. Potcenjena pasiva utiče na formiranje manje visine rashoda u Bilansu uspeha i povećanje obračunatog kratkoročnog finansijskog rezultata. Svaki skriveni gubitak u Bilansu stanja otkriva se u Bilansu uspeha u narednim obračunskim periodima. Otkrivanje skrivenih gubitaka zavisiće od brzine dospeća obaveza. Latentne rezerve i skriveni gubici, kvare sliku o finansijskoj poziciji 
konkretnog preduzeća. Stoga, treba težiti njihovom minimiziranju, odnosno, svođenju dugoročnih rezervisanja na njihovu realnu vrednost.

\section{DUGOROČNA REZERVISANJA KAO ALAT ZA SMANJENJE POSLEDICA NEADEKVATNOG KVALITETA}

Novi zahtevi u pogledu kvaliteta proizvoda i usluga uvećavaju rizik poslovanja i navode preduzeće da se sve više oslanja na sredstva koje je rezervisalo. Kupci će biti sve zahtevniji u pogledu reklamacija i ukoliko preduzeće ne izdvaja sredstva na posebnom računu moraće da se suoči sa velikim troškovima nekvaliteta. U Republici Srbiji, prema Pravilniku o kontnom okviru i sadržni računa u kontnom okviru za privredna društva, zadruge, pravna lica i preduzetnike postoje sledeće vrste rezervisanja u okviru grupe 40 Dugoročna rezervisanja: rezervisanja za troškove $\mathrm{u}$ garantnom roku; rezervisanja za troškove obnavljanja prirodnih bogatstava; rezervisanja za zadržane kaucije i depozite; rezervisanja za troškove restruktuiranja; rezervisanja za naknade i druge beneficije zaposlenih; rezervisanja za troškove sudskih sporova; ostala dugoročna rezervisanja. ${ }^{2}$

Za predmet ovog istraživanja, najvažnija vrsta su rezervisanja za troškove $\mathrm{u}$ garantnom roku, koja mogu obezbediti preduzeće od rizika vraćenih proizvoda. Osnovni razlog formiranja rezervisanja za ovu namenu jeste jačanje pozicije kupaca $\mathrm{u}$ odnosu na proizvođača, kao i sve veći zahtevi i stalno proširivanje asortimana proizvoda čija je prodaja praćena davanjem garancija.

Činjenica da je neophodno ne samo implicitno, već i eksplicitno upravljati troškovima nekvaliteta, odnosno, neodgovarajućeg kvaliteta opravdava predmet istraživanja. Slika 2 pokazuje značaj dugoročnih rezervisanja $u$ savremenim uslovima poslovanja.

Mogućnost da se pojavi određeni broj zahteva za ispunjenje obaveza po osnovu datih garancija može stvoriti velike troškove preduzeću. Usled rizika i neizvesnosti nastanka ove obaveze, postoji potreba za izdvajanjem određenih novčanih sredstava. Naime, obaveza formiranja rezervisanja za troškove u garantnom roku nastaje zbog toga što vremenski period trajanja garancije prelazi obračunski period u kome je izvršena prodaja. Prošli događaj, koji je obavezujući za priznavanje ovog računa jeste prodaja robe, po osnovu koje je nastala sadašnja obaveza tj. obećanje da će se pokriti troškovi popravke $u$ garantnom roku. Prema tome, sigurno je da će doći do odliva novčanih sredstava, dok su iznos i rok dospeća neizvesni. Utvrđivanje visine rezervisanja najčešće se bazira na dosadašnjem iskustvu za istu, ili sličnu robu. Imajući u vidu probleme koji se mogu javiti prilikom obuhvatanja ovih poslovnih transakcija, koje su posledica nestabilne računske podloge i nemogućnosti apsolutne tačne alokacije prihoda $\mathrm{i}$ rashoda, poređenje računovodstvene prakse ima važnu ulogu (Malinić, 2009). Ukoliko prethodno nije bilo troškova po ovom osnovu, procena rezervisanja se vrši posmatrajući konkurenciju u istoj grani. Naravno, visina rezervisanja zavisi od obima prodaje, pa se najčešće i izražava $u$ procentu od ostvarene prodaje. Rezervisanje se vrši grupno, tj. za grupu proizvoda. Međutim, ukoliko preduzeće u svom asortimanu ima veliki broj proizvoda sa različitim verovatnoćama i rizicima za reklamaciju, onda moraju da se naprave određene grupe proizvoda za koja će se priznati rezervisanja. Pod uslovom da preduzeće kontinuirano prodaje proizvode na koje daje garanciju, rezervisanje za troškove u garantnom roku ima karakter kontinuiranog rezervisanja.

"Po definiciji, dugoročna rezervisanja predstavljaju obaveze za pokrivanje troškova i rizika iz prethodnih aktivnosti koji će se pojaviti u narednim godinama" (Lukić, 2017, 455). U tom smislu, pretpostavka je da dugoročna rezervisanja predstavljaju mehanizam uz pomoć kojeg je moguće efikasno upravljati troškovima eksternih otkaza, a u cilju obezbeđenja od rizika usled njihovog pojavljivanja. Vizibilnost, odnosno uvid $\mathrm{u}$ tokove i procese koji se nastavljaju van preduzeća, postaje važna osnova dobrog poslovanja preduzeća. Preuzimanje rizika davanja garancija za proizvode, $\mathrm{u}$ 


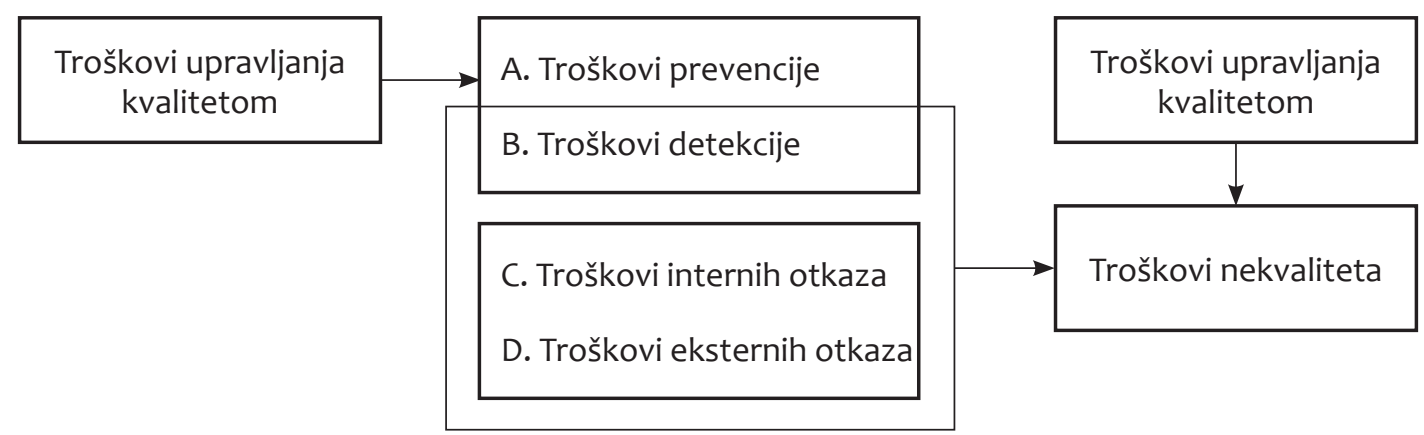

Slika 2 Značaj dugoročnih rezervisanja u matrici troškova

Izvor: Autori

savremenim uslovima poslovanja, stvara troškove koje je veoma teško proceniti. „Za komercijalne proizvode, cena i garancija su dve ključne marketinške strategije, koje se koriste za povećanje tržišnog učešća" (Xie, 2017). Na značaj garancija ukazao je pre više decenija. Naime, J. Mamer (1987), izlaže svoj model troškova i koristi koje nastaju po osnovu garancija. Razmatra tri tipa garancije proizvoda, kao i potencijalne štete koje nastaju usled izostanka kvaliteta. Njegov model predstavljao je osnovu za dalje analize kompromisa između garancije i kontrole kvaliteta.

Studija koja je sprovedena u Grčkoj, takođe, naglašava značaj dugoročnih rezervisanja u ulozi smanjenja troškova nekvaliteta. Prema ovoj studiji, $89 \%$ dugoročnih rezrvisanja ima ulogu u smanjenju troškova nekvaliteta (Chatzipetrou \& Moschidis, 2016). Prema S. Amberkar-u i N. M. Jagtap-u (2014), dugoročna rezervisanja zavise od vrste garancije, pouzdanosti proizvoda, garantnog perioda i vrste proizvoda. Veći broj kupaca kupuje proizvode u zavisnosti od produžene garancije, koju bi kompanije mogle da obezbede jedino ukoliko se oslone na relevantan instrument kontrolinga (Maronick, 2007).

Neznatan broj istraživanja na temu uticaja dugoročnih rezervisanja na upravljanje troškovima kvaliteta, realizovan je na primeru preduzeća u Republici Srbiji. Prema R. Lukiću (2014), stopa povraćaja robe od prodaje postaje sve značajniji pokazatelj nivoa satisfakcije potrošača i performansi maloprodajnih lanaca. Komparativnom analizom povraćaja robe $\mathrm{u}$
Sjedinjenim Američkim Državama i Kanadi, autor istražuje uticaj dugoročnih rezervisanja na dobit i ukazuje na to da adekvatnom kontrolom treba minimizirati efekat povraćaja. Autor je sproveo teorijsku i empirijsku analizu uticaja dugoročnih rezervisanja na troškove eksternih otkaza. Prema autoru, troškovima eksternih otkaza je neophodno efikasno upravljati u cilju sticanja što većeg profita. Analizira troškove garancije prema vrsti robe i naglašava da je povraćaj, ili zamena proizvoda zbog neodgovarajućeg kvaliteta, stvorio velike troškove u brojnim industrijama. Rezultati istraživanja pokazuju da su dugoročna rezervisanja sve važniji faktor poslovne uspešnosti maloprodaje.

Radi ispitivanja veze između dugoročnih rezervisanja i neto dobitka, kao rezultata poslovanja preduzeća, korišćeni su podaci sa sajta Agencije za privredne registre u Republici Srbiji. U analizu je uključeno prvih 100 preduzeća, sa liste najuspešnijih prema neto dobitku u 2017. Ovakva analiza trebalo bi da, uz apstrahovanje ostalih faktora, pokaže da li prisustvo dugoročnih rezervisanja može biti dovedeno u vezu sa uspešnošću poslovanja preduzeća. Rezultati korelacione analize dati su u Tabeli 1.

Prema nivou značajnosti od 0,000 može se konstatovati da između posmatranih varijabli postoji pozitivna korelacija. Vrednost Pearsonovog koeficijenta korelacije od 0,472 pokazuje da je ova veza umerena (Cohen, 1988), ali, svakako statistički značajna, što opravdava uverenje, odnosno, potvrđuje 
polaznu pretpostavku da dugoročna rezervisanja mogu biti koristan mehanizam kontrolinga kada je reč o troškovima eksternih otkaza u smislu zaštite neto dobitka preduzeća.

Tabela 1 Pearsonov koeficijent korelacije

\begin{tabular}{ll|cc}
\hline & & $\begin{array}{c}\text { Dugoročna } \\
\text { rezervisanja }\end{array}$ & $\begin{array}{c}\text { Neto } \\
\text { dobitak }\end{array}$ \\
\hline \multirow{2}{*}{$\begin{array}{llc}\text { Kugoročna } \\
\text { rezervisanja }\end{array}$} & $\begin{array}{l}\text { korelacijent } \\
\text { Nivo } \\
\text { značajnosti } \\
\text { Veličina uzorka }\end{array}$ & 1,000 &, $472^{* *}$ \\
\hline \multirow{2}{*}{$\begin{array}{l}\text { Neto } \\
\text { dobitak }\end{array}$} & $\begin{array}{l}\text { Koeficijent } \\
\text { korelacije }\end{array}$ &, $472^{* *}$ & 1,000 \\
& $\begin{array}{l}\text { Nivo } \\
\text { značajnosti }\end{array}$ &, 000 & \\
& Veličina uzorka & 100 & 100 \\
\hline
\end{tabular}

** Korelacija je značajna na nivou 0.01 level (dvostrano).

Izvor: Autori

Imajući u vidu da u grupi prvih 100 najuspešnijih dominiraju velika preduzeća, da bi se mogla steći slika o trendu kada je reč o izdvajanjima preduzeća na ime dugoročnih rezervisanja (između ostalog i za pokriće troškova u garantnom roku), analizirana je razlika u trendu po kategorijama velika, srednja i mala preduzeća, na bazi podataka iz objavljenih finansijskih izveštaja obveznika Agencije za privredne registre, u periodu 2006-2017 (Tabela 2).

Mala i srednja preduzeća su imala približno jednaku dinamiku dugoročnih rezervisanja u posmatranom periodu. Najveća relativna promena u poslednjoj u odnosu na prvu godinu odnosi se na mala preduzeća, koja su imala i najveću prosečnu godišnju promenu dugoročnih rezrvisanja. Naime, u ovim preduzećima su dugoročna rezervisanja povećavana po prosečnoj stopi od 24,18\% godišnje. Srednja preduzeća su zabeležila nešto manju prosečnu godišnju promenu $(21,27 \%)$, dok je najmanja relativna promena zabeležena u velikim preduzećima, gde je prosečna godišnja stopa iznosila 10,75\%.
Tabela 2 Relativne promene dugoročnih rezervisanja (u \%), 2006-2017.

\begin{tabular}{c|ccc}
\hline Godina & Mala & Srednja & Velika \\
\hline 2006. & - & - & - \\
2007. & $41,98 \%$ & $30,99 \%$ & $28,68 \%$ \\
2008. & $3,10 \%$ & $36,41 \%$ & $35,26 \%$ \\
2009. & $112,41 \%$ & $-0,91 \%$ & $26,92 \%$ \\
2010. & $46,18 \%$ & $11,38 \%$ & $7,38 \%$ \\
2011. & $39,40 \%$ & $1,73 \%$ & $2,06 \%$ \\
2012. & $-25,08 \%$ & $35,35 \%$ & $23,83 \%$ \\
2013. & $38,13 \%$ & $3,00 \%$ & $12,37 \%$ \\
2014. & $-16,49 \%$ & $88,31 \%$ & $-23,31 \%$ \\
2015. & $-3,77 \%$ & $17,49 \%$ & $3,09 \%$ \\
2016. & $24,24 \%$ & $8,36 \%$ & $18,33 \%$ \\
2017. & $5,86 \%$ & $1,90 \%$ & $-16,42 \%$ \\
\hline Promena & $593,05 \%$ & $583,25 \%$ & $163,43 \%$ \\
\hline $2017 / 2006$ & $24,18 \%$ & $21,27 \%$ & $10,75 \%$ \\
\hline Prosečna godišnja & & & \\
promena & &
\end{tabular}

Izvor: Autori

Analiza varijanse pokazala je da ne postoji statistički značajna razlika između stope promene dugoročnih rezervisanja (nivo značajnosti iznosi 0,524) u posmatranim preduzećima, prema veličini (Tabela 3).

\section{ZAKLJUČAK}

Značaj troškova nekvaliteta, a među njima posebno troškova eksternih otkaza, nije samo u vremenskom periodu njihovog pojavljivanja i njihovoj veličini, već i u posledicama koje mogu da izazovu svojim nastankom. Uočen od strane kupaca, izostanak kvaliteta može da donese neuspeh $u$ poslovanju preduzeća. Troškovi eksternih otkaza nastaju vraćanjem proizvoda, servisiranjem, reklamacijama i ostalim intervencijama usmerenim ka nezadovoljnim potrošačima. Kada nastanu troškovi nekvaliteta, aktiviraju se dugoročna rezervisanja, čija je funkcija smanjenje posledica. Dakle, dugoročna rezervisanja se pojavljuju kao instrument zaštite od rizika vraćenih 
Tabela 3 Analiza varijanse

\begin{tabular}{l|ccccc}
\hline & Suma kvadrata & Diskontni faktor & Prosek kvadrata & F & Nivo značajnosti \\
\hline Između grupa & 1099,123 & 2 & 549,561 &, 660 &, 524 \\
Unutar grupa & 24989,945 & 30 & 832,998 & & \\
Ukupno & 26089,068 & 32 & & & \\
\hline
\end{tabular}

Izvor: Autori

proizvoda. Kao efikasan instrument, mogu da pokriju sve ili deo troškova koji nastaju usled vraćenih proizvoda. Preduzeće je sposobno da odgovori na reklamacije, što zaustavlja dalju reakciju nezadovoljnih potrošača, koju bi imali prema potencijalnim kupcima da proizvodi nisu zamenjeni u garantnom roku. Kada je preduzeće sposobno da proizvode zameni u garantnom roku i odgovori na intervencije kupaca, pri čemu svoje poslovanje može nesmetano da nastavi, ono uz pomoć dugoročnih rezrvisanja pokriva nastale troškove i ne dolazi do poslovanja sa gubitkom. Na ovaj način, preduzeće utiče i na smanjenje troškova eksternih otkaza. Na osnovu ranijih garancija, preduzeće ima pravo da rezerviše unapred sredstva i obezbedi se od rizika. Upravljanjem dugoročnim rezrvisanjima, preduzeće smanjuje posledice nastale usled uočavanja nekvaliteta od strane potrošača, brže reguje na problem i ne posluje sa gubitkom. S druge strane, potrošač je zadovoljan, jer je na vreme došlo do intervencije kojom su ispunjeni njegovi zahtevi.

Za efikasnim alatom upravljanja troškovima nekvaliteta se još uvek traga. Ipak, na osnovu rezultata istraživanja, može se reći da dugoročna rezervisanja mogu biti relevantan mehanizam za upravljanje troškovima eksternih otkaza, kao dela ukupnih troškova kvaliteta.

U savremenim uslovima poslovanja, postoji potreba za praćenjem troškova upravljanja kvalitetom, a posebno troškova eksternih otkaza, imajući u vidu da ovi troškovi pokazuju tendenciju rasta (Anđelković Pešić, 2009). Na osnovu izloženog, jasno je da su posledice izostanka kvaliteta negativne. Najbolji argument jeste da reklamacije ne odražavaju pravu sliku o konkretnom preduzeću i stvaraju "halo" efekat. To stvara sumnju u poslovanje preduzeća. Instrument kontrolinga, dugoročna rezervisanja, koji se tretira kao najosetljivija bilansna pozicija, izaziva promenu u troškovima i utiče na finansijski rezultat. Ukoliko entitet ne rezerviše sredstva, on preuzima preveliki rizik da apsorbuje troškove nekvaliteta, sa kojima je danas teško opstati na tržištu. U radu se naglašava da veći iznosi dugoročnih rezervisanja mogu omogućiti preduzeću da umanji posledice i da upravlja troškovima eksternih otkaza, te da dugoročna rezervisanja mogu poboljšati poslovanje preduzeća. Naglašavanjem uloge dugoročnih rezervisanja, povećava se svest o važnosti kontrolinga u funkcionisanju preduzeća.

Cilj uvođenja dugoročnih rezervisanja u polje upravljanja kvalitetom jeste da se ispita značaj rezervisanja kao mehanizma praćenja i pokrivanja troškova eksternih otkaza, ali i da se postavi osnova za dalja istraživanja. Naime, eliminisanje troškova nekvaliteta, pre nego što proizvodi počnu da se koriste od strane potrošača, nije izvodljivo za svako preduzeće. Iz tog razloga, neophodno je umanjiti sve potencijalne posledice koje mogu nastati usled izostanka kvaliteta. U radu je dat odgovor na sledeća pitanja: da li dugoročna rezervisanja pružaju obezbeđenje od rizika nastanka troškova eksternih otkaza, kao i, da li upravljanje dugoročnim rezervisanjima umanjuje posledice koje nastaju usled izostanka kvaliteta proizvoda?

Rezultati rada pokazuju da dugoročna rezervisanja predstavljaju značajan alat upravljanja troškovima eksternih otkaza. Time je dokazana polazna pretpostavka da dugoročna rezervisanja mogu biti efikasan alat upravljanja troškovima kvaliteta. U radu je izvršena je analiza dugoročnih rezervisanja i neto dobitka prvih 100 preduzeća na listi najuspešnijih prema neto dobitku u Republici Srbiji u 2017. Rezultati korelacione analize pokazuju pozitivnu, 
statistički značajnu korelaciju između dugoročnih rezervisanja i neto dobitka preduzeća. Prosečna godišnja promena dugoročnih rezervisanja najveća je u malim preduzećima. Najmanja relativna promena dugoročnih rezervisanja $\mathrm{u}$ posmatranom periodu (2006-2017), zabeležena je u velikim preduzećima, gde je prosečna godišnja stopa iznosila 10,75\%, što pokazuje da velika preduzeća daju veći značaj dugoročnim rezervisanjima $u$ odnosu na srednja $\mathrm{i}$ mala.

Imajući u vidu prethodno, potrebno je afirmisati procenu dugoročnih rezervisanja koja neće zavisiti od dužine poslovanja preduzeća, već će biti povezana sa rizikom poslovanja $u$ jednoj industriji. Analiza prikazana u radu je i od društvenog interesa, jer doprinosi povećanju opreznostii značaja realne procene dugoročnih rezervisanja. Istini za volju, savršeno finansijsko izveštavanje ne postoji ne samo $\mathrm{u}$ zemljama $\mathrm{u}$ razvoju, nego ni $\mathrm{u}$ zemljama razvijenih privreda. Jednostavno, poslovni život svakog subjekta je kompleksan, a prosuđivanje iznosa koji će biti ukalkulisani u bilansima podrazumeva niz varijabilnih faktora koji se moraju uzmati $\mathrm{u}$ obzir. Najvažnije je, prema tome, imati saznanje o negativnim stranama troškova eksternih otkaza, što će uvećati opreznost pri procenjivanju samog iznosa dugoročnih rezervisanja.

Svojevrsno ograničenje u sprovođenju istraživanja predstavlja relativno mali broj radova u okviru stručne literature o dugoročnim rezervisanjima u kontekstu njihovog uticaja na upravljanje troškovima eksternih otkaza. Ograničenje sprovedenog istraživanja je i nedovoljna transparentnost bilansa dovoljnog broja preduzeća, koji su neophodni za sprovođenje odgovarajuće empirijske analize. Takođe, nedostatak podataka o dugoročnim rezervisanjima za troškove u garantnom roku onemogućava ispitivanje veze između ove kategorije dugoročnih rezervisanja i neto dobiti, kojom bi se dobila jasnija slika o vezi između ovih varijabli, te i o uticaju dugoročnih rezervisanja, u smislu zaštite od troškova eksternih otkaza na finansijski rezultat preduzeća. Sprovedena analiza bilansa posmatranih preduzeća, na osnovu koje su u radu formulisani opšti zaključci o dugoročnim rezervisanjima, nije dovoljna da se uzorak proglasi reprezentativnim, a rezultati empirijskog istraživanja statistički značajnim, ali se uzorak, svakako, može smatrati informativnim, a analiza osnovom za dalja istraživanja u ovoj oblasti. Konačno, autori smatraju da bi se potpunijim empirijskim istraživanjem mogla pružiti jasnija slika o ovom mehanizmu, što bi, svakako, doprinelo i promisanju njegovog značaja za upravljanje troškovima eksternih otkaza.

\section{ENDNOTE}

1 U trgovačkom zakonu, do IV Direktive Evropske ekonomske zajednice, data je mogućnost priznavanja rezervisanja za troškove koji su izazvani u protekloj godini. Na primer, vršena su rezervisanja za održavanje kapaciteta, za velike popravke, itd.

2 U ranijim zakonima iz oblasti računovodstva, u Srbiji se moglo izvršiti rezervisanje za troškove investicionog održavanja, paušalno rezervisanje za pokriće dubioznih potraživanja, rezervisanja za rizik po osnovu rasta cena na malo i kurseva stranih valuta, rezervisanja na osnovu revalorizacionog dobitka, rezervisanja za odloženi negativni gudvil itd.

\section{REFERENCE}

Agencija za privredne registre Republike Srbije, Makroekonomska saopštenja 2006-2017. godine. Retrieved Oktober 21, 2018, from www.apr.gov.rs/Регистри / Финансијскиизвештаји/Макроекономскасаопштења. aspx

Ali, H., Arif, W., Pirzada, D., Khan, A., \& Hussain, J. (2012). Classical model based analysis of cost of poor quality in a manufacturing organization. Journal of Business Management, 6(2), 670-680.

Amberkar, S., \& Jagtap, M. M. (2014). Warranty cost modelling and analysis. International Journal of Scientific \& Engineering Research, 5(12), 40-44.

Anđelković Pešić, M. (2009). Modeli upravljanja troškovima kvaliteta. Računovodstvo, Jul-Avgust, 64-75.

Baiman, S., Fischer, P., \& Rajan, M. (2000). Information, contracting, and qualitiy costs. Management Science, 46(6), 776-789. doi:10.1287/mnsc.46.6.776.11939 
Bamford, D., \& Land, N. (2006). The application and use of the paf quality costing model within a footwear company. International Journal of Quality \& Reliability Management, 23(3), 265-278. doi.org/10.1108/02656710610648224

Barbará, C., Eutrópio, C., de Souza, E., \& Catunda, R. (2008). Modeling the cost of poor quality. WSC 08. Proceedings of the 40th Conference on Winter Simulation, 1437-1441.

Bisgaard, S. (2007). Quality management and jurans legacy. Quality and Reliability Engineering International, 23(6), 665677. doi:10.1002/qre.860

Bošković, G. i Anđelković Pešić, M. (2011). Upravljanje kvalitetom - osnova konkurentnosti preduzé́a i privrede. Nišs, Republika Srbija: Ekonomski fakultet Univerziteta u Nišu.

Brandt, L., Biesebroeck, J. V., \& Zhang, Y. (2012). Creative accounting or creative destruction? Firm-level productivity growth in Chinese manufacturing. The National Bureau of Economic Research, NBER Working Paper No. 15152.

Campanella, J. (1999). Principles of quality costs: Principles, implementation, and use. Annual Quality Congress Proceedings, 53(0), 507-508.

Chatzipetrou, E., \& Moschidis, O. (2016). Quality costing: A survey in Greek supermarkets using multiple correspondence analysis. International Journal of Quality \& Reliability Management 33(5), 615-632. doi.org/10.1108/ IJQRM-01-2014-0004

Chi Tsou, J. (2007). Economic order quantity model and Taguchi's cost of poor quality. Applied Mathematical Modeling, 31(2), 283-291. doi.org/10.1016/j.apm.2005.11.007

Cohen, J. (1988). Statistical Power Analysis for the Behavioral Sciences. (2nd ed.). Hillsdale, NJ: Lawrence Erlbaum Associates, Publishers.

Đukić, T., \& Pavlović, M. (2014). Creative accounting and cash flows reporting. Facta Universitatis-Economics and Organization, 11(3), 227-235.

Eben-Chaime, M. (2013). A note on: The economic effects of quality improvements. Total Quality Management \& Business Excellence, 24(3-4), 374-377.

Feigenbaum, A. V. (1994). Controle da qualidade total: Gestão e sistemas. São Paulo, Brazil: Makron Books.

Fu, F., \& Zhang, T. (2016). A new model for solving timecost-quality trade-off problems in construction. PLOS ONE 11(12), e0167142, doi.org/10.1371/journal.pone.0167142
IAS 37 - Резервисања, потенцијалне обавезе и потенцијална имовина. IFRS, Retrieved Oktober 13, 2018, from https:// www.ifrs.org/.

Krishnan, S., Agus, A., \& Husain, N. (2000). Costs of quality: The hidden costs. Total Quality Management, 11(4-6), 844848. doi:10.1080/09544120050008309

Krstić, B., Anđelković Pešić, M., \& Anđelković, A. (2010). Managing the variations in time, quality of realization and outputs of activities with the aim of encreasing efficiency of business process. Economic Themes, 48(3), 345-354.

Lukić, R. (2014). Utjecaj povrata roba na performanse u maloprodaji. Ekonomski pregled 65(1), 89-104.

Lukić, R. (2017). The impact of long-term provision costs on performance of trade in Serbia. Economic and Environmental Studies, 17(3), 455-474. doi: 10.25167/ees.2017.43.1

Malinić, D. (2009). Savremeni izazovi integralnog istraživanja kvaliteta finansijskih izveštaja. Ekonomika preduzeća, 57(3-4), 138-155.

Malmi, T., Järvinen, P., \& Lillrank, P. (2004). A collaborative approach for managing project cost of poor quality. European Accounting Review, 13(2), 293-317. doi:10.1080/0963818042000204733

Mamer, J. (1987). Discounted and per unit costs of product warranty. Management Science, 33(7), 916-930.

Maronick, T. (2007). Consumer perceptions of extend warranties. Jorunal of Retailing and Consumer Sevices, 14(3), 224-231. doi:10.1016/j.jretconser.2006.09.003

Raupp, F. M., \& Gaebler, D. M. (2016). Identification and measurement of quality costs and non quality in a textile and apparel industry. Systems $\mathcal{E}$ Management, 11, 282-289. doi:10.20985/1980-5160.2016.v11n3.1104

Sailaja, A., Basak, P., \& Viswanadhan, K. (2015). Hidden costs of quality: Measurement \& analysis. International Journal of Managing Value and Supply Chains (IJMVSC), 6(2), 13-25. doi:10.5121/ijmvsc.2015.6202.

Satanova, A., \& Sedliacikova, M. (2015). Model for controling the total costs of quality. Procedia-Economics and Finance. 26, $2-6$.

Schiffauerova, A., \& Thomason, V. (2006). A review of research on cost of quality models and best practices. International Journal of Quality and Reliability Management, 23(4), 1-23. doi:10.1108/02656710610672470 
Teli, S. N., Majali, V., Bhushi, U., \& Surange, V. (2012). Assessment of cost of poor quality for automobile industry. International Journal of Engineering Research and Applications, 2(6), 330-336.

Teli, S. N., Majali, V. S., Bhushi, U., \& Surange, V. G. (2014). Impact of poor quality cost in automobile industry. International Journal of Quality Engineering and Technology, 4(1), 1757-2185. doi:10.1504/IJQET.2014.059842.

Vučićević, V., \& Anđelković Pešić, M. (2012). Quantification of quality: The iddicators of justification of the improvement of processes and product quality. Facta Universitates Economics and Organization, 9(4), 495-506.
Wojtaszek, H. (2015). Role of managerial accounting in the innovative enterprise. World Scientific News (WSN), 57(2016), 652-658.

Xie, W. (2017). Optimal pricing and two-dimensional warranty policies for a new product. International Journal of Production Research, 55(22), 6857-6870. doi.org/10.1080/00207 543.2017.1355578

\section{Primljeno 12. novembra 2018, nakon revizije, prihvaćeno za publikovanje 17. aprila 2019. Elektronska verzija objavljena 25. aprila 2019.}

Milica Ristić je student doktorskih studija Ekonomskog fakulteta Univerziteta u Nišu, gde je angažovana u svojstvu studenta demonstratora. Oblasti njenog interesovanja su: javne finansije, fiskalna politika, siva ekonomija, finansijsko izveštavanje i bankarstvo.

Radenko Milojević je redovni profesor na Ekonomskom fakultetu Univerziteta u Nišu. Doktorirao je na Ekonomskom fakultetu u Subotici, Univerziteta u Novom Sadu. Izvodi nastavu na nastavnim predmetima: Upravljanje resursima preduzeća, Menadžment ljudskih resursa, Agencijsko poslovanje, Međunarodni menadžment ljudskih resursa, Upravljanje poslovnim procesima, Upravljanje karijerom i Troškovi u poslovnom odlučivanju. Ključne oblasti njegovog interesovanja su: funkcionisanje preduzeća, upravljanje ljudskim resursima, upravljanje poslovnim procesima.

Marija Radosavljević je vanredni profesor na Ekonomskom fakultetu Univerziteta u Nišu. Doktorirala je na Ekonomskom fakultetu Univrziteta u Beogradu. Ključne oblasti njenog naučnog interesovanja su: upravljanje kvalitetom, upravljanje poslovnim procesima, upravljanje troškovima, upravljanje ljudskim resursima. 


\title{
LONG-TERM PROVISIONS AS A SECURITY MECHANISM DUE TO LACK OF QUALITY
}

\author{
Milica Ristic, Radenko Milojevic and Marija Radosavljevic \\ Faculty of Economics, University of Nis, Nis, The Republic of Serbia
}

Modern business conditions have been decisively indicating that the basis of the company's competitiveness is quality. The lack of quality creates dissatisfaction and affects customer loyalty. Lately, there has been a tendency of the growth of non-quality costs, which is a consequence of the lack of quality of the products delivered. Although numerous studiess have models for calculating non-qualitative costs, no relevant mechanism has yet been found to manage these costs. In this study, the authors attempted to find a link between long-term provisions and the cost of external failure, which is dealt with by a small number of researchers. The aim of the research is to point out the importance of long-term provisions, which can be a relevant control instrument in managing the external failure costs. Survey confirmed the initial assumption, and showed that long-term provisions are an effective instrument for managing the costs of external failure. Also, on the case of first 100 enterprises on the list of the most successful in the Republic of Serbia in 2017, a positive, statistically significant correlation between long-term provisions and net profit of the company was identified.

Keywords: quality, quality costs, external failure costs, long-term provisions

JEL Classification: L52, M21, M41 